Summer 7-21-2021

\title{
Pediatric Sepsis-Development of a Clinical Pathway for the Pediatric Emergency Department
}

\author{
Roslyn Lampkin-Smiley \\ University of St Augustine for Health Sciences, r.lampkinsmiley@usa.edu
}

DOI: https://doi.org/10.46409/sr.OIHO6908

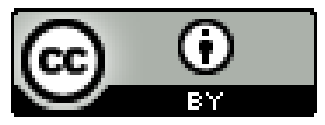

This work is licensed under a Creative Commons Attribution 4.0 License.

Follow this and additional works at: https://soar.usa.edu/scholprojects

Part of the Emergency Medicine Commons, Other Medical Specialties Commons, and the Other Nursing Commons

\section{Recommended Citation}

Lampkin-Smiley, R. (2021). Pediatric Sepsis-Development of a Clinical Pathway for the Pediatric Emergency Department. [Doctoral project, University of St Augustine for Health Sciences]. SOAR @ USA: Student Scholarly Projects Collection. https://doi.org/10.46409/sr.OIH06908

This Scholarly Project is brought to you for free and open access by the Student Research at SOAR @ USA. It has been accepted for inclusion in Student Scholarly Projects by an authorized administrator of SOAR @ USA. For more information, please contact soar@usa.edu, erobinson@usa.edu. 
Pediatric Sepsis-Development of a clinical pathway for the

Pediatric Emergency Department

Roslyn Lampkin-Smiley, BSN, RN

School of Nursing, University of St. Augustine for Health Sciences

This Manuscript Partially Fulfills the Requirements for the

Doctor of Nursing Practice Program and is Approved by:

Robin Kirschner, EdD, DNP, RN

Janis Quinn, DNP, APRN, CPNP-AC

Approved: July 18, 2021 


\begin{abstract}
Globally, various researchers have suggested that sepsis is one of the most prominent causes of infant fatalities. Since 2004, countless guidelines have been developed to assist in the early identification and management of sepsis. The PICOT question that guided this project was: Does the implementation of a pediatric sepsis clinical pathway, compared with the standard protocol in emergency departments, decrease delays in treatment times of patients presenting with sepsis? Researchers have suggested that early recognition and interventions for septic patients can result in decreased mortality rates. A pediatric sepsis clinical pathway was implemented during this project. The pathway alerted staff members when a pediatric patient was experiencing sepsisrelated symptoms. The pathway included various interventions (e.g., administration of intravenous fluids and antibiotics) and treatment goals (i.e., treatment within 60 minutes of arrival time) for clinical staff members to employ with potential septic patients. The implementation of this intervention resulted in earlier pediatric sepsis recognition and a decrease in delay in the treatment of sepsis symptoms. Implementing a protocol that is specific to pediatric patients presenting to the emergency department for sepsis can increase the recognition of sepsis symptoms and can also decrease treatment times. Implementing this protocol may also decrease patient length of stays and can possibly decrease the propensity of organ damage and other sepsis- related complications.
\end{abstract}




\section{Pediatric Sepsis-Development of a Clinical Pathway for the Pediatric Emergency Department}

Globally, sepsis is the most common cause of death in the pediatric population, resulting in 7.5 millions deaths annually and a 25\% mortality rate (Mathias et al., 2016). Researchers have noted that early detection and goal-directed therapy for pediatric sepsis leads to improved patient outcomes (Lloyd et al., 2018). However, in the early stages when treatment is most effective, sepsis can be indistinguishable from other febrile illnesses (Riley et al., 2012). Findings denote the benefits of implementing a pediatric sepsis protocol bundle, thereby resulting in expedited care, reduced hospital length of stay (LOS), and decreased mortality (Balamuth et al., 2017).

The purpose of this practice change project was to implement an evidence-based clinical pathway to increase the recognition of sepsis among pediatric patients who presented to the Emergency Department (ED). The aim of this project was to decrease the delay in treatment times for septic patients, which can result in decreased LOS, reduced patient complications, and lowered patient mortality rates.

\section{Significance of the Practice Problem}

According to Riley et al. (2012), on average, children with sepsis have a LOS of approximately one month, which equates to a total of $\$ 40,000$ per admission. Since the findings were published by Riley et al. (2012), McIntosh et al. (2017) noted a total of $\$ 77,00$ cost per pediatric sepsis admission, a Pediatric Intensive Care Unit (PICU) LOS of 7 days, and long-term morbidity for sepsis survivors. Pediatric sepsis survivors experience impaired health, which extends far beyond hospital discharge (Han et al., 2017). In fact, sepsis survivors often develop 
residual renal function issues, increased hypertension risks, and chronic kidney disease (Starr et al., 2020). Kawasaki (2017) found that many children who have reportedly died from other underlying conditions actually die from sepsis. Wheeler et al. (2011) noted that the presence of co-morbid conditions, such as prematurity and congenital heart disease, increase the risk of mortality in children with sepsis.

In 2003, the Surviving Sepsis Campaign (SSC) was formed by critical care and infectious disease experts (Dellinger et al., 2004). The purpose of the SSC was to develop evidence-based guidelines to aid in the early identification and management of sepsis among children (Weiss et al., 2020). The SSC guidelines are intended to guide best practice, but they are not meant to replace the decision-making skills utilized by clinicians (Weiss et al., 2020). The guidelines indicate the critical importance of early assessment and treatment options for sepsis patients.

Using sepsis bundles can improve patient-related outcomes (Levy et al., 2018). At the selected project site, a pediatric ED-specific sepsis protocol was not offered. To ensure that early physician evaluations occur, the timely initiation of ED nursing staff care is critical (Larsen et al., 2011). As noted by Larsen et al. (2011), for each unrecognized and untreated hour of septic shock, the mortality rate can increase twofold. Therefore, the implementation of this project was beneficial, as it resulted in an increase the recognition of sepsis symptoms and a decrease in treatment time for pediatric sepsis patients.

\section{PICOT Question}

By utilizing the PICOT format, the researcher was able to answer a question by identifying the population $(\mathrm{P})$, intervention $(\mathrm{I})$, comparisons $(\mathrm{C})$, outcomes $(\mathrm{O})$, and time frame (T). The PICOT questions asked, "In pediatric patients, 18 years of age or younger, who 
presented to the Emergency Department (ED), did the implementation of a pediatric sepsis clinical pathway, compared with the standard pediatric ED protocol, decrease delays in treatment times of septic patients to less than 60 minutes from recognition of sepsis symptoms, within an eight-week time frame?

\section{Population/Problem}

According to Balamuth et al. (2017), in the United States alone, more than 75,000 children are treated each year for severe sepsis. Of those 75,000 children treated for sepsis, a $20 \%$ mortality rate was present and approximately $\$ 4.8$ billion dollars in health care costs were incurred (Balamuth et al., 2017). Recognizing sepsis, during its early stages, can be difficult because children have the ability to adapt and physiologically compensate to stressors (Thompson \& Macias, 2015). Researchers have indicated that failure to recognize the signs of septic shock and delays in intravenous (IV) fluid and antibiotic administration has resulted in poor outcomes among pediatric patients (Paul et al., 2017). Paul et al. (2017) also found that pediatric patients who received $60 \mathrm{ml} / \mathrm{kg}$ of an isotonic IV fluid within 60 minutes of arrival to the ED, experienced shorter hospital length of stays.

\section{Intervention}

The intervention was implemented in a Pediatric Emergency Department and involved the utilization of a pediatric sepsis clinical pathway. The pathway included a best practice alert (BPA), which was implemented in EPIC (an electronic health record [EHR]). The ED nursing staff, upon entering the patient's vital information (symptoms, vital signs), would be alerted if the information entered signaled a potential sepsis patient. The purpose of the BPA was to alert the staff nurse of a possible sepsis patient, which would in turn cause the staff nurse to notify the physician of a potential septic patient. If the physician suspected sepsis, treatment orders would 
be immediately initiated. The pathway provided the ED staff with concrete guidance associated with interventions and time sensitive treatment goals to care for pediatric sepsis.

\section{Comparison}

Although the organization's adult ED utilizes a sepsis clinical pathway, there was not an established protocol for pediatric patients. Appropriate sepsis-related symptoms and treatment for adults greatly differs compared to symptoms and treatment for pediatric patients. Utilizing data from an adult clinical pathway is not appropriate (Riley et al., 2012). Intervention metrics from previous pediatric septic patients was compared with intervention metrics from pediatric septic patients after the clinical pathway was implemented to evaluate the success of the project.

\section{Outcome}

The outcome of this project was an increased recognition of symptoms associated with pediatric sepsis, thereby resulting in a decreased treatment time for sepsis. The sepsis pathway included various interventions, such as rapid initiation of an IV access, administration of fluid resuscitation, antibiotic administration, and the initiation of a vasopressor (Kessler et al., 2016). According to Medicare Hospital Compare (n.d.), at Central DuPage Hospital, which was the selected project site, $57 \%$ of patients received appropriate care for severe sepsis and septic shock. Unfortunately, the average care rate at Central DuPage Hospital was lower than the Illinois average of $60 \%$ and the national average of $59 \%$ (Medicare, n.d.). It is important to note that the site does not separate pediatric sepsis versus adult sepsis reporting.

\section{Timeline}


This project was implemented over an eight-week period. Staff were educated by the outcomes manager and the nurse manager before the project's official start date. Additionally, staff members and project site stakeholders were provided with weekly project-related updates for the purpose of keeping the staff abreast of the project's progress.

\section{Evidence-Based Practice Framework \& Change Theory}

The John Hopkins' nursing evidence-based practice model was used to guide this project. The major focus of this model is the translation of best evidence for nurses to use in care decisions, as the model addresses all of the important components of the evidence-based practice process (Schaffer et al., 2013). The model includes three major steps, which are (1) identification of the practice question, (2) collection of the evidence; and (3) translation of the evidence for use in practice (Schaffer et al., 2013).

Havelock's theory of planned change was the selected change theory utilized during this project. Havelock's theory targets the resistance to change that is often experienced by participants (Myers, 2017). Havelock's change theory was also chosen for this project because of its alignment with internal problem solving, social interaction, research-based development and diffusion in innovation adoption (Farmer, 2012). The stages of Havelock's theory include: Ccare; R-relate; E-examine; A-acquire; T-try; E-extend; and R-renew (Christenbery, 2017).

The Care stage of Havelock's theory includes determining that a problem exists or recognizing an opportunity for a positive change (Christenbery, 2017). For the purpose of this project, the Care stage was identified when the need for a pediatric-specific clinical pathway was determined. During the Relate stage, relationships are developed with the stakeholders (Christenbery, 2017). The relate stage was successfully carried out as the project team, comprised of members from various disciplines and backgrounds, was chosen. The Examine 
stage includes creating a foundation for problem solving (Christenbery, 2017). A meeting with several stakeholders at the clinical site revealed a pressing need for a sepsis clinical pathway for pediatric patients who presented to the ED for treatment. Given this pressing need, a collaborative team was created and the process of developing the pathway for project implementation began.

Resources are gathered during the Acquire stage (Christenbery, 2017). To ensure the successful implementation of the Acquire stage, the project team enlisted the help of a quality coaching program, which is known as the Academy for Quality and Safety Improvement (AQSI), to facilitate the change process. The final three stages of Havelock's theory include the Try stage, the Extend stage, and the Renew stage. For this project, solutions were identified during the Try stage, implementation occurred during the Extend stage, and reinforcement of the process occurred in the Renew stage (Christenbery, 2017). Implementation of the project began once protocols were successfully in place, to successfully accomplish the Try stage and the Extend stage.

Individuals are often resistant to change, thereby reinforcing the critical nature of effective staff communication, staff education, and support systems (Wagner, 2018). The researcher engaged the team members and updated them about the project's progress throughout the entirety of this process. By ensuring consistent communication, the researcher sought to convey that the input, ideas, opinions, etc. of the team mattered. Once the change occurred, continuous monitoring was imperative. The purpose of continuous monitoring is to ensure the processes do not revert back to the original state (Myers, 2017). Continuous monitoring will include annual education competencies for the ED staff and integration of the clinical pathway into the EMR system. 


\section{Evidence Search Strategy}

A search of the literature was performed using the Cumulative Index to Nursing and Allied Health Literature (CINAHL), OVID, and Public Medline (PubMed). Various keywords were used to gather project-related research. The keywords selected were pediatric sepsis, septic shock, bundles or protocols, and emergency department or emergency room. The search was limited to academic journals in the English language that were published between 2015 and 2020. The search resulted in 56 articles from CINAHL, 32 articles from OVID, and 335 articles from PubMed. Articles were further limited by ensuring that the patient population were children (18 years of age and under), were those being treated in the Emergency Department, and were limited to patients who presented with symptoms of sepsis or septic shock.

\section{Evidence Search Results}

The final literature search yielded 10 articles. Of the ten articles that met the inclusion criteria for this literature search, common recurring themes related to the benefits of early recognition of sepsis, the importance of early intervention, and the impact of those actions in decreasing mortality rates. The remaining articles were chosen based on their relevancy to the PICOT question. A summary of the primary research (Appendix A) and systematic reviews (Appendix B) identified the important outcome metrics associated with increase staff adherence to protocols, decreased treatment times, decreased hospital length of stay, and decreased patient mortality.

The selected articles were evaluated using the Johns Hopkins Nursing Evidence-Based Practice Guide (Dearholt, \& Dang, 2012). The evaluation of the articles was included in Figure 1. Of the articles chosen for inclusion, nine of the articles were Level II articles, which is reflective of quality articles. One of the articles was a Level I, which is reflective of a high- 
quality article. A high-quality article covers relevant literature on a topic, not confined to one research methodology, focuses on concepts, and is complete (Webster \& Watson, 2002). The findings of the literature review support the use of a screening tool for early recognition and treatment of sepsis patients in the pediatric emergency department.

\section{Themes with Practice Recommendations}

The project question asked, 'Did the implementation of a pediatric sepsis clinical pathway, compared with the standard pediatric ED protocol, decrease delays in treatment times of septic patients to less than 60 minutes from recognition of sepsis symptoms, within an eightweek time frame? The literature was reviewed to identify recurring themes which included implementation of a sepsis protocol, early sepsis recognition, and timely treatment of sepsis symptoms.

\section{Sepsis Protocol}

The most recurring theme, in the literature, was the implementation of a sepsis protocol for pediatric patients who presented to the ED with symptoms of septic shock. Most of the resources supported the use of a sepsis protocol in caring for pediatric sepsis patients (Arikan et al., 2015; Balamuth et al., 2017; Evans et al., 2018; Gigli et al., 2020; Lane et al., 2016; Larsen et al., 2011; Lloyd et al., 2018; Long et al., 2016; Mittal et al., 2019). A primary outcome derived from the use of the protocol included an improved recognition and treatment of sepsis (Lane et al., 2016).

Although most research findings supported the use of a sepsis protocol, one study noted that a shortage of nursing staff would cause delays in the initiation of portions of the protocol (Mittal et al., 2019). Another study noted that although the sepsis protocol is helpful in 
recognizing septic patients, clinician judgment and physical examination is also of critical importance (Balamuth et al., 2017). According to Cruz (2017), the perfect pediatric sepsis protocol includes recognition of vital sign abnormalities, identification of physical examination findings, and recognition of abnormal laboratory findings. The aforementioned findings should be incorporated into the site's electronic health record and implemented in all pediatric EDs and EDs in which children are treated.

\section{Early Sepsis Recognition/Timely Treatment}

Another theme noted in the literature was the importance of early recognition of septic shock symptoms among pediatric patients (Arikan et al., 2015; Balamuth et al., 2017; Lane et al., 2016; Larsen et al., 2011; Lloyd et al., 2018; Mittal et al., 2019). In addition to the importance of early sepsis symptom recognition, various researchers highlighted the critical nature of timely sepsis treatment (Arikan et al., 2015; Lane et al., 2016; Larsen et al., 2011). Furthermore, the American College of Critical Care Medicine (ACCM) noted that ideal pediatric septic shock care includes rapid identification of the condition, restoration of normal perfusion, and proper administration of antibiotics (Tuuri et al., 2016).

Timely treatment of pediatric sepsis includes administration of an intravenous fluid bolus and antibiotics within one hour of sepsis recognition (Evans et al., 2018). In addition to fluids and antibiotics, pediatric septic patients may also require vasopressors and steroids (Arikan et al., 2015). The timely diagnosis and treatment of pediatric septic shock can prevent organ damage, morbidity, and mortality (Scott et al., 2020).

\section{Practice Recommendations}


The research addressed the PICOT question and reinforced that the implementation of a pediatric sepsis protocol decreased hospital length of stay, decreased organ dysfunction, and decreased mortality (Evans et al., 2018). Based on the conclusions in the research, a pediatric sepsis protocol should be implemented to increase recognition and timely treatment of pediatric patients, who present to the ED, with symptoms of septic shock. Protocol compliance, specifically when treating patients with sepsis, resulted in an $8 \%$ decreased mortality rate (Qian et al., 2016).

Before the implementation of this project, pediatric ED nurses participated in an educational session regarding the use of the sepsis protocol. The training included a video, printed learning material, pre- and post-tests, and return demonstrations. The educational material included practice sessions in the EPIC environment, use of the protocol, and testing material on the signs and symptoms of pediatric sepsis. Compliance with the use of the protocol and patient outcomes will be monitored to determine the effectiveness of the protocol.

\section{Setting, Stakeholders, and Systems Change}

This project took place in a pediatric Emergency Department of a hospital that is located in the western suburbs of Chicago, Illinois. The 390-bed hospital provides cardiovascular, neurology, oncology, pediatric, pulmonary, and surgical services (Northwestern Medical Center, n.d.). Patients who frequent the ED are infants and children, ranging in age from newborn to 18 years of age, who require emergency care.

The hospital's mission is 'a health system of caregivers who aspire to consistently high standards of quality, academic and research excellence, cost-effectiveness, and patient satisfaction, where the patient comes first' (Northwestern Medical Center, n.d.). The hospital's vision is 'to seek to improve the health of the communities we serve by delivering a broad range 
of services with sensitivity to the individual needs of our patients and their families'

(Northwestern Medical Center, n.d.). The mission and vision of the organization aligns with the project's mission of delivering quality care to the pediatric population.

\section{Organizational Structure}

This organization is a part of a larger network located in the heart of Chicago, that has been continuously ranked as one of the top 10 hospitals by US News and World Report (Northwestern Medical Center, n.d.). The larger organization has a total of 10 additional hospitals, multiple urgent care centers, and outpatient facilities (Northwestern Medical Center, n.d.). The organizational structure includes a Chief Executive Officer and President, a Chief Financial Officer and Senior Vice-President, and a Chief Operating Officer. The structure also includes a Chief Nursing Officer, a Chief Medical Officer, directors, managers, and front-line staff (Northwestern Medical Center, n.d.).

\section{Organizational Culture}

The culture of the organization includes a shared leadership and decision-making model, where the health care team works together to achieve the goals of the organization (Northwestern Medical Center, n.d.). The organization is committed to patient-centered treatment and an evidence-based approach to care that is centered on each patient's unique circumstances (Northwestern Medical Center, n.d.). A Relationship-Based Care Model is utilized in the organization that supports the safety and patient experience, fosters patient care transitions, and embraces diversity and inclusivity (Northwestern Medical Center, n.d.). The organization, dedicated to quality outcomes and excellence in nursing practice, is also a magnet designated facility (Northwestern Medical Center, n.d.). 


\section{Organizational Need}

As a result of the organizational needs assessment, it was determined that pediatric patients presenting to the ED for septic shock symptoms were being treated differently based on the provider working in the ED. This also posed a problem in that care was sometimes delayed longer than necessary for those septic patients. A gap analysis was indicated to identify the gap in knowledge of recognition and treatment of pediatric septic shock patients. The needs assessment and gap analysis revealed the need to develop a standardized protocol to be utilized by the pediatric ED staff.

\section{Stakeholders}

A stakeholder analysis determined the key stakeholders to be included in this project. A stakeholder analysis included understanding the attributes and interrelationships of the potential participants, as well as identifying the needs and expectations of the project (Smith, 2000). Stakeholders include the ED Medical Director, Chief Nursing Officer, the Chief Financial Officer, the ED Outcomes Manager, Information Technology (IT) Manager, ED physicians, ED Nurse Practitioners, and ED staff nurses.

\section{Organizational Support}

The support for the project was provided by the ED physicians, nurse practitioners, ED Outcomes Manager, and the preceptor for the project. Effective organizational support included forums where the project team can openly discuss problems that are being encountered (Johns, 1999). Open communication within the group was necessary in recognition of problems at an early stage in the project (Johns, 1999).

\section{Sustainability}


Some aspects of sustainability included time, as well as innovation (Sadaba \& PerezEzcurdia, 2015). A training program, with a yearly renewal, will be provided to all of the ED staff that will be using the protocol. Integrating the new protocol into the EMR system will increase project sustainability.

\section{Interprofessional Collaboration}

This project consisted of interprofessional collaboration from all the stakeholders as well as the participants utilizing the protocol. The implementation of the protocol was the priority of this project, however compliance with use of the protocol was addressed in this project as well. Training and inclusion of the staff helped to ensure compliance with the use of the protocol.

\section{Strength, Weakness, Opportunity, and Threat Analysis}

A Strength, Weakness, Opportunity, and Threat (SWOT) Analysis was conducted to determine the organization's ability to successfully implement the change project (Appendix C). Some of the strengths included in the analysis were stakeholder support and monetary support from the organization. Weaknesses included resistance by staff to utilize the protocol and no active protocol in place. Threats include poor health and treatment outcomes for pediatric septic patients without a protocol in place and loss of staff if forced to utilize the protocol. Opportunities include the implementation of the project in other pediatric EDs in the organization.

\section{Implementation Plan with Timeline and Budget}

\section{Objectives}


The objective of this project was to successfully implement a pediatric sepsis pathway to guide the clinical care of pediatric sepsis patients resulting in better outcomes.

\section{Early Recognition}

Early recognition was key to the success of this project. This involved the revision of the best practice alert for pediatric patients to improve sensitivity in identifying sepsis patients early, leading to rapid implementation of the sepsis pathway.

\section{Aggressive Treatment}

Another goal of this project was the aggressive treatment of the pediatric sepsis patient which included rapid intravenous fluid resuscitation, administration of an antibiotic, labs, and the administration of vasopressors for persistent hypoperfusion despite fluid resuscitation.

\section{Staff Compliance}

The last goal of this project was to obtain a $90 \%$ compliance from staff in utilizing the sepsis protocol by week eight of the project. During a meeting with the ED manager, dissatisfaction with the current process was recognized, and the need to improve the management of the pediatric sepsis patients was identified. To help ensure compliance, the ED staff was trained on use of the protocol, with annual refresher courses offered. Staff were kept abreast of the progress of the project by email, which included any successes or any changes that were implemented. Monthly meetings with staff and stakeholders allowed for input from staff on how the project was progressing.

\section{Project Plan}


The change model that was used to guide the change project is Havelock's Theory of Planned Change because of the model's focus on planning and accepting change (Myers, 2017). Havelock's model includes the steps needed to implement the change project as well as focus on any resistance to the project by the staff.

The project manager for this project was chosen based on her leadership abilities and the ability to manage the project from start to finish. A successful project manager has to perform various roles and must possess leadership skills, interpersonal skills, communication skills, and problem-solving skills (Zulch, 2014). The project required interprofessional collaboration between the project manager and all other members involved in the change project. Poor interprofessional collaboration can have a negative impact on the quality of patient care (Bridges et al., 2011).

The project also included financial considerations with a spreadsheet attached (Table 1) that addressed the possible direct and indirect costs, as well as the revenue. Costs included the training of the staff on the use of the protocol. The training can be successfully completed in 6 to 8 hours with a nurse's rate of pay at approximately $\$ 40 /$ hour. Supplies included medications such as antibiotics and vasopressors, IV fluids, and supplies for lab draws such as needles and blood collection tubes. IT was responsible for downloading the protocol into EPIC, which may require additional software or software upgrade. Overhead included the cost of running the facility (mortgage, electricity bill, gas bill, water bill, etc.). Office supplies included computers, pens, paper and ink for printing the protocol and other educational materials. Revenue included the estimated cost of a visit in the Pediatric ED, which incorporates the visit, a physician's fee, medications, labs, and other costs included in the visit. The budget for this project included 
money from stakeholders and the organization and any additional costs associated with the project that was pre-approved by the CFO.

\section{Havelock's Planned Change Model}

The six steps of Havelock's model include: (1) Care; (2) Relate; (3) Examine; (4) Acquire; (5) Try; (6) Extend; and (7) Renew (White, 2019). This model guided the change project and described how the change would be utilized and implemented.

Care: includes attention to the need for change (White, 2019). The organization recognized that the current practice utilized for treatment was not effective. It was determined that there was a need for a protocol that was specific to the pediatric ED exclusively. A literature review regarding pediatric sepsis and sepsis protocols was completed.

Relate: a relationship must be developed between all the stakeholders where communication is two-way and honest (Myers, 2017). Meetings with the stakeholders and open communication with all parties involved ensured a healthy relationship throughout the project. Meetings occurred at least bi-weekly and included email correspondence as needed. Members of leadership such as $\mathrm{CEO}$ and $\mathrm{CNO}$ were invited to attend bi-weekly meetings to help garner continued support for the project.

Examine: diagnosing the problem and making a decision as to whether or not a change is needed and how to proceed with that change (Myers, 2017). After deciding that a pediatric sepsis protocol was needed, the proposal was completed and submitted to IRB for approval.

Acquire: gathering the data and resources needed to proceed with the change (Myers, 2017). Webinars on leadership and project planning were completed to ensure that the project 
manager was knowledgeable about the subject matter of the project as well as understood how to successfully complete the project.

Try: choosing the method of change and beginning implementation of the project (Myers, 2017). The protocol chosen did mimic the protocol used by the organization's standalone pediatric hospital. The protocol was downloaded into EPIC for use by the staff.

Extend: disseminating and gaining acceptance from the staff (White, 2019). Change must be accepted and become part of the staff's new behavior (Myers, 2016). Implementation of the project began in week 5 and monitoring for compliance with the protocol begin thereafter.

Renew: monitor the change and continue the cycle (Myers, 2017). Data was collected and analyzed at the end of the project on April 30, 2020.

\section{Results}

The process of evaluation includes determining the safety and effectiveness of a system, providing guidance to the implementation process, and mitigating any unplanned negative outcomes (Sligo et al., 2017). The plan evaluated whether the implementation and adherence to a pediatric sepsis protocol in the pediatric ED would decrease morbidity and mortality for septic patients presenting to the ED for treatment.

The impact evaluations were executed at the end of the project and determined if the project was successful in its intended focus. Participants included those patients from birth to 18 years of age that presented to the pediatric ED with symptoms of sepsis. Pediatric ED nurses were tasked with entering the patients' information into EPIC and filling out the sepsis goals form (called the 'Blue Sheet). Each nurse received educational training on the BPA and the sepsis goals form. A comparison of pre-implementation data to post-implementation data was 
evaluated to determine the effectiveness of the sepsis pathway. The 'Blue Sheet', established by the Pediatric Outcomes Manager, was used to collect the data (Appendix G). Data was collected before implementation of the change project and weekly or bi-weekly after the implementation of the project. A quantitative analysis of the data was completed.

The project manager, the DNP student, for this change project was responsible for collecting, analyzing, and storing the data. The proposal was submitted to the University's EPRC for approval and afterwards submitted to the organization's reviewing committee for approval. The project qualified for expedited approval, as the project was a known evidence-based practice. The project posed minimal risk, however ethical issues were closely monitored, which included patient privacy and the protection of human rights All paper data was stored in a filing cabinet in a locked room with keypad access to the project manager and her assistant. Electronic data was stored in the organization's secured and HIPAA compliant database that is secured with encryption software. Access to the project's data was limited to the project manager, the assistant to the project manager, the pediatric ED manager, and the medical director of the Pediatric ED, to ensure that the participants sensitive information was protected. Utilizing a second person (nurse, nurse practitioner, or physician) to review the data collected helped to ensure accuracy and address any missing data concerns.

Process measures included the timeliness of the initial assessment of the patient and recognition of sepsis symptoms; compliance with the use of the clinical pathway; the timeliness of administration of a fluid bolus; and timeliness of antibiotic administration. Outcome measures included a decrease in ICU admissions, a decrease in hospital LOS, and a decrease in patient mortality. Balancing measures included a false positive rate and patients being sent home without antibiotics. 
There was sustainability for the change project as the clinical pathway can be implemented in the pediatric ED after the project is completed. The pathway can then be implemented in the organization's remaining pediatric EDs that currently do not have a pediatric sepsis pathway in use.

\section{Variables}

The independent variable identified for this project is the implementation of the clinical pathway in EPIC. The dependent variable for this project is the treatment times for pediatric patients that are suspected to have sepsis. The dependent variable will be used to determine if the clinical pathway is effective in decreasing treatment times in these patients.

\section{Data Analysis}

Before deciding if the implementation of a clinical pathway could reduce the number of fatalities of pediatric patients with sepsis, we had to examine some important statistical information. The program Intellectus was used to insert the data and conduct an analysis of that data. The total number of cases in the population examined was 16 . To determine if there was a correlation between the clinical pathway and treatment administration, an independent sample $\mathrm{T}$ test was conducted. A p value of 0.5 was used to determine if the data collected was statistically significant. The data was gathered from the Pediatric Emergency Room and aimed to determine if implementing a clinical pathway could reduce complications in those patients that were suspected of having sepsis. When the Best Practice Alert (BPA) fired in EPIC, the nurse was instructed to complete a Sepsis Goals form (Appendix G).

The first relationship examined was between the implementation of a clinical pathway and the administration of a fluid bolus. The data suggests there was not a significant difference 
between the implementation of a clinical pathway and the administration of a fluid bolus $(\mathrm{p}<.05$, $\mathrm{p}=67)$. Since the $\mathrm{p}$ value was greater than .05 . the null hypothesis was retained. The second relationship examined was between the implementation of a clinical pathway and the administration of an antibiotic. The data suggests there was not a significant difference between the use of a clinical pathway and the administration of an antibiotic $(p<.05, p=40)$. The null hypothesis was retained in this relationship as well. A factor that could have potentially contributed to the null hypothesis being retained was the sample size. The lack of a larger sample size can impact the significance of the data.

There were a total of 16 pre-interventions charts and 10 post-intervention charts that were analyzed as a potential for pediatric sepsis. From those charts, 12 pre-intervention charts and 4 post-intervention charts were ultimately included in the final analysis portion of the project. These charts included all points of data included, where the excluded charts did not contain all points of data. Reasoning for the lack of the points of data indicated that the patient possibly was only treated for hypovolemia rather than sepsis.

Out of the 10 post-intervention charts utilized, a huddle with the nurse and ED provider was initiated. The huddle afforded the opportunity for the nurse to alert the physician to the possibility that the patient could potentially be septic, so that the patient could be seen by the provider and immediate treatment initiated. Also of note, the provider orders for IV boluses were consistently done within a 60-minute time frame, however the antibiotic order time lags behind significantly. Although the implementation of the sepsis huddle and pathway improved this, there is still work to be done. The culture has previously been to wait for the lab results before initiating treatment, specifically the white blood cell count and the absolute neutrophil count 
(ANC). There has been much discussion of antibiotic stewardship as well, which may have contributed to the delay in ordering antibiotics. More research is needed in this area.

The delay in fluid and antibiotic administration did however significantly decrease during the intervention. Both of these interventions rely on a multitude of factors, including the adequacy of nurse staffing, the ability to gain IV access quickly, and the efficiency of the pharmacy. But the improvement suggests that the urgency in which the nurse is implementing the orders has increased. This is an important finding that demonstrates that the entire care team needs to be aware of the importance of rapid intervention for sepsis patients. When all are included in the process, the patient benefits.

\section{Impact}

The aim of this project sought to increase the recognition of sepsis in pediatric patients that presented to the ED. A major finding of this project included an increase in recognition of possible septic patients. Each time the clinical pathway fired, the nurse called a huddle with the charge nurse and the provider to determine if the patient needed a septic workup, which ultimately led to a reduced treatment time for the patient. The ED nurses can play a major role in the ongoing implementation of the clinical pathway by continuing to recognize the firing of the pathway and acting in accordance with the treatment plan.

The project was a pilot in the PEDS ED that will be continued after the completion of this initial study. Although the nurses are responsible for the use of the pathway itself, the outcomes manager will be responsible for the sustainability of the project. In order for the project to be successful, there must be a commitment from the stakeholders, the ED providers, and the ED nurses. The staff must be willing to incorporate the pathway into their daily work routine on a consistent basis. In addition to staff participation, there must be additional funding for this 
project. The additional funding will be used for the continued education and recertification of the nurses, as well as for any IT issues that may arise with the pathway.

One of the barriers during this project was the misfiring of the pathway in EPIC. The problem occurred as the pathway appeared to be firing when the patient wasn't potentially septic but wouldn't fire when the patient was potentially septic. Although the issue with the pathway was fixed, potential data was lost during the collection phase of the project.

Another barrier during this project was the presence of COVID-19. Because of COVID, the census in the ED was significantly lower than pre-pandemic, which could have contributed to the lower number of potentially septic patients presenting to the ED. Providers' initial focus was ruling out the presence of COVID in those patients presenting with fever and other symptoms that are similar to sepsis. The loss of time waiting on results of a COVID screening also affected the treatment times during this project. These barriers could also be a contributing factor to the small amount of data collected for this project. Although there was a clinical significance in this project, data collection will continue well beyond the scope of this project.

\section{Dissemination Plan}

After completion of the project, feedback from the preceptor, mentor, and Pediatric ED faculty was elicited to determine any opportunities for improvement. Dissemination included a presentation with the participants in the project, the medical director of the Pediatric ED, the CNO, the medical director of the adult ED, department managers, and support staff in the ED. The presentation included power point slides and charts for viewing result data.

External dissemination of the project will include a presentation at a conference such as the annual conference of the Society of Pediatric Nurses (SPN). This group represents the 
advancement of pediatric nursing through research and education, which is why it was chosen for dissemination. Plans for journal submission include the Pediatrics journal as it is the most cited journal in pediatric medicine and is the official flagship journal of the American Academy of Pediatrics (American Academy of Pediatrics, N.D.).

External dissemination will also include submitting the scholarly paper to the University's repository for publication. The repository, SOAR@USA, is managed by the University's library staff and includes scholarly work from students, faculty, and alumni of USAHS. Studies indicate that publishing in a reputable open access journal is associated with versatility, higher citation rates, visibility, and an increase likelihood that the published work will be shared om social media (Cuschieri, 2018).

\section{Conclusion}

Although sepsis results in the death of approximately 7.5 million pediatric patients annually, most of the current treatment for pediatric sepsis is extrapolated from adult studies (Mathias et al., 2016). Using a protocol that is specific to the pediatric population can increase the recognition of sepsis symptoms and decrease the treatment time for these patients. Literature supports that implementing timely care for pediatric sepsis patients decreases hospital length of stay and mortality rates. The pediatric sepsis protocol can be implemented in the organization within eight weeks and with staff compliance, the protocol can be maintained in the organization long-term. 


\section{References}

Balamuth, F., Alpern, E., Abbadessa, M., Hayes, K., Schast, A., Lavelle, J., Fitzgerald, J., Weiss, S., \& Zorc, J. (2017). Improving recognition of pediatric severe sepsis in the emergency department: Contributions of a vital sign-based electronic alert and bedside clinician identification. Annals of Emergency Medicine, 70(6), 759-768.

https://doi.org/10.1016/j.annemergmed.2017.03.019

Christenbery, T. (2017). Evidence-based practice in nursing: Foundations, skills, and roles. New York, NY: Springer Publishing. Retrieved from: https://www.springerpub.com/evidencebased-practice-in-nursing-9780826127426.html

Cruz, A. (2017). Between the devil and the deep blue sea: Use of real-time tools to identify children with severe sepsis in the pediatric emergency department. Annals of Emergency Medicine, 70(6), 769-770. https://doi.org/10.1016/j.annemergmed.2017.04.006

Cuschieri S. (2018). WASP: Is open access publishing the way forward? A review of the different ways in which research papers can be published. Early Human Development, 121, 54-57. https://doi.org/10.1016/j.earlhumdev.2018.02.017

Dearholt, S.L., \& Dang, D. (2012). Johns Hopkins Nursing Evidence-Based Practice Model and Guidelines ( $2^{\text {nd }}$ ed.). Indianapolis, Indiana: Sigma Theta Tau International.

Dellinger, P., Carlet, J., Masur, H., Gerlach, H., Calandra, T., Cohen, J., Gea-Banacloche, J., Keh, D., Marshall, J., Parker, M., Ramsay, G., Zimmerman, J., Vincent, J., \& Levy, M. (2004). Surviving sepsis campaign: Guidelines for management of severe sepsis and septic shock. Critical Care Medicine, 32(3), 858-873. https://doi.org/10.1097/01.CCM.0000117317.18092.E4 
Farmer, L. (2012). Technology and change processes in knowledge systems. Recent Advances in Communications, Circuits, and Technological Innovation, Retrieved from: Available: http://www.wseas.us/e-library/conferences/2012/Paris/CICOCOM/CICOCOM-14.pdf

Han, M., Fitzgerald, J., Balamuth, F., Keele, L., Alpern, E., Lavelle, J., Chilutti, M., Grundmeier, R., Nadkarni, V., Thomas, N., \& Weiss, S. (2017). Association of delayed antimicrobial therapy with one-year mortality in pediatric sepsis. Shock, 48(1), 29-35. https://doi.org/10.1097/SHK.0000000000000833

Johns, T. (1999). On creating organizational support for the Project Management Method. International Journal of Project Management, 17(1), 47-53. https://doi.org/10.1016/S0263-7863(97)00062-8

Kawasaki, T. (2017). Update on pediatric sepsis: A review. Journal of Intensive Care, 5(47), 112. https://doi.org/10.1186/s-40560-017-0240-1

Kessler, D., Walsh, B., Whitfill, T., Gangadharan, S., Gawel, M., Brown, L., \& Auerbach, M. (2016). Disparities in adherence to pediatric sepsis guidelines across a spectrum of emergency departments: A multicenter, cross-sectional observational in situ simulation study. The Journal of Emergency Medicine, 50(3), 403-415. https://doi.org/10.1016/j.jemermed.2015.08.004

Larsen, G., Mecham, N., \& Greenberg, R. (2011). An emergency department septic shock protocol and care guideline for children initiated at triage. Pediatrics, 127(6), e15851592. https://doi.org/10.1542/peds.2010-3513 
Levy, M.M., Evans, L.E., \& Rhodes, A. (2018). The surviving sepsis campaign bundle: 2018 update. Intensive Care Medicine, 44, 925-928. https://doi.org/10.1007/s00134-018-5085$\underline{0}$

Lloyd, J., Ahrens, E., Clark, D., Dachenhaus, T., \& Nuss, K. (2018). Automating a manual sepsis screening tool in a pediatric emergency department. Applied Clinical Informatics, 8(4), 803-808. https://doi.org/10.1055/s-0038-1674211

Long, E., Babl, F., Angley, E., \& Duke, T. (2016). A prospective quality improvement study in the emergency department targeting pediatric sepsis. Archives of Diseases in Childhood, 101, 945-950. https://doi.org/10.1136/archdischild-2015-310234

Mathias, B., Mira, J., \& Larson, S. (2016). Pediatric sepsis. Current Opinion in Pediatrics, 28(3), 380-387. https://doi.org/10.1097/MOP.0000000000000337

McIntosh, A., Tong, S., Deakyne, S., Davidson, J., \& Scott, H. (2017). Validation of the vasoactive-inotropic score in pediatric sepsis. Pediatric Critical Care Medicine, 18(8), 750-757. https://doi.org/10.1097/PCC.00000000000001191

Medicare. (n.d.). Hospital compare quality of care page. Retrieved from: https://www.medicare.gov/hospitalcompare/profile.html\#profTab=2\&ID=140242\&loc= WINFIELD\%2C\%20IL\&lat=41.8616956\&lng=$\underline{\text { 88.1609031\&name }=\text { CENTRAL } \% 20 \text { DUPAGE\%20HOSPITAL\&Distn }=1.0}$

Moher, D., Liberati, A., Tetzlaff, J., Altman, D.G., The PRISMA Group (2009). Preferred Reporting Items for Systematic Reviews and Meta-Analyses: The PRISMA Statement. PloS Med 6(7): e1000097. Doi:10.1371/journal.pmed1000097

Myers, C. (2017). Elements of change. Perspectives in Learning, 16(1), 15-18. 
Paul, R., Melendez, E., Wathen, B., Larsen, G., Chapman, L., Wheeler, D., Wakefield, T., \& Macias, C. (2017). A quality improvement collaborative for pediatric sepsis: Lessons learned. Pediatric Quality and Safety, 3(1), e051. https://doi.org/10.1097/pq9.000000000000005

Qian, J., Wang, Y., Zhang, Y., Zhu, X., Rong, Q., \& Wei, H. (2016). A survey of the first-hour basic care tasks of severe sepsis and septic shock in pediatric patients and an evaluation of medical simulation on improving the compliance of the tasks. The Journal of Emergency Medicine, 50(2), 239-245. https://doi.org/10.1016/j.jemermed.2015.05.040

Randolph, A., \& McCulloh, R. (2014). Pediatric sepsis: Important considerations for diagnosing and managing severe infections in infants, children, and adolescents. Virulence, 5(1), 179-189. https://doi.org/10.4161/viru.27045

Riley, C., Basu, R., Kissoon, N., \& Wheeler, D. (2012). Pediatric sepsis: Preparing for the future against a global scourge. Current Infectious Disease Report, 14, 503-511. https://doi.org/10.1007/s11908-012-0281-5

Schaffer, M.A., Sandau, K.E., \& Diedrick, L. (2013). Evidence-based practice models for organizational change: Overview and practical applications. Journal of Advanced Nursing, 69(5), 1197-1209. https://doi.org/10.1111/j.1365-2648.2012.06122.x

Scott, H., Kempe, A., Davies, S., Krack, P., Leonard, J., Rolison, E., Mackenzie, J., Wathen, B., \& Bajaj, L. (2020). Managing diagnostic uncertainty in pediatric sepsis quality improvement with a two-tiered approach. Pediatric Quality and Safety, 1(5), e244. https://doi.org/10.1097/pq9.0000000000000244 
Sligo, J., Gauld, R., Roberts, V., \& Villa, L. (2017). A literature review for large-scale health information system project planning, implementation and evaluation. International Journal of Medical Informatics, 97, 86-97. https://doi.org/10.1016/j.ijmedinf.2016.09.007

Smith, L.W. (2000). Stakeholder analysis: A pivotal practice of successful projects. Paper presented at Project Management Institute Annual Seminars \& Symposium, Houston, TX. Newton Square, PA: Project Management Institute.

Starr, M., Banks, R, Reeder, R., Fitzgerald, J., Pollack, M., Meert, K., McQuillen, P., Mourani, P., Chima, R., Sorenson, S., Varni, J., Hingorani, S., \& Zimmerman, J. (2020). Severe acute kidney injury is associated with increased risk of death and new morbidity after pediatric shock. Pediatric Critical Care Medicine, 21(9), e686-e695. https://doi.org/10.1097/PCC.00000000000002418

Thompson, G., \& Macias, C. (2015). Recognition and management of sepsis in children: Practice patterns in the emergency department. The Journal of Emergency Medicine, 49(4), 391399. https://doi.org/10.1016/j.jemermed.2015.03.012

Tuuri, R., Gehrig, M., Busch, C., Ebeling, M., Morelia, K., Hunt, L., \& Russell, S. (2016). Beat the shock clock: An interprofessional team improves pediatric septic shock care. Clinical Pediatrics, 55(7), 626-638. https://doi.org/10.1177/00009922815601984

Wagner, J. (Ed.). (2018). Leadership and Influencing Change in Nursing. Regina, SK: UR Press. Retrieved from: https://ourspace.uregina.ca/handle/10294/8296

Webster, J., \& Watson, R. (2002). Analyzing the past to prepare for the future: Writing a literature review. MIS Quarterly, 26(2), xiii-xxiii. 
Weiss, S., Peters, M., Alhazzani, W., Agus, M., Flori, H., Inwald, D., Nadel, S., Schlapbach, L., Tasker, R., Argent, A., Brierly, J., Carcillo, J., Carroll, E., Carroll, C., Chiefetz, I., Choong, K., Cies, J., Cruz, A., De Luca, D., Deep, A., Faust, S., De Oliveira, C., Hall, M., Ishimine, P., Javouhey, E., Joosten, K., Joshi, P., Karam, O., Kneyber, M., Lemson, J., MacLaren, G., Mehta, N., Moller, M., Newth, C., Nguyen, T., Nishisaki, A., Nunnally, M., Parker, M., Paul, R., Randolph, A., Ranjit, S., Romer, L., Scott, H., Tume, L., Verger, J., Williams, E., Wolf, J., Wong, H., Zimmerman, J., Kissoon, N., \& Tissieres, P. Surviving sepsis campaign international guidelines for the management of septic shock and sepsis-associated organ dysfunction in children. Intensive Care Medicine, 46(Suppl 1), S10-S67. https://doi.org/10.1007/s00134-019-05878-6 a de

Wheeler, D., Wong, H., \& Zingarelli, B. (2011). Pediatric sepsis-part 1: Children are not small adults. Open Inflammatory Journal, 7(4), 4-15. https://doi.org/10.2174/1875041901104010004

White, K., Dudley-Brown, S., \& Terhaar, M. (2019). Translation of evidence into nursing and healthcare ( $3^{\text {rd }}$ ed.). New York, NY: Springer Publishing Company.

Zulch, B. (2014). Leadership communication in project management. Procedia Social and Behavioral Sciences, 119, 172-181. https://doi.org/10.1016/j.sbspro.2014.03.021 
Table 1

Budget

\begin{tabular}{|c|l|l|c|}
\hline EXPENSES & REVENUE & \\
\hline Direct & & $\begin{array}{l}\text { Billing (ER visit, physician fee, } \\
\text { medications, labs, etc.) \$1,500 per } \\
\text { patient x 10 patients }\end{array}$ & 15,000 \\
\hline $\begin{array}{l}\text { Salary and training of staff } \\
\text { on use of protocol (10 } \\
\text { nurses, 8 hours, \$40/hr. pay) }\end{array}$ & 3,200 & Grants & \\
\hline $\begin{array}{l}\text { Supplies: Medications, IV } \\
\text { fluids, lab supplies }\end{array}$ & 1,500 & Institutional budget support & \\
\hline $\begin{array}{l}\text { Services: IT/ } \\
\text { implementation of protocol } \\
\text { into EMR }\end{array}$ & 500 & & 9,650 \\
\hline Statistician & 5,350 & Total Revenue & \\
\hline $\begin{array}{l}\text { Printing/copying protocol, } \\
\text { paper/office supplies }\end{array}$ & 150 & & \\
\hline Indirect & & & \\
\hline Overhead & & & \\
\hline Net Balance & & & \\
\hline
\end{tabular}


PRISMA Figure
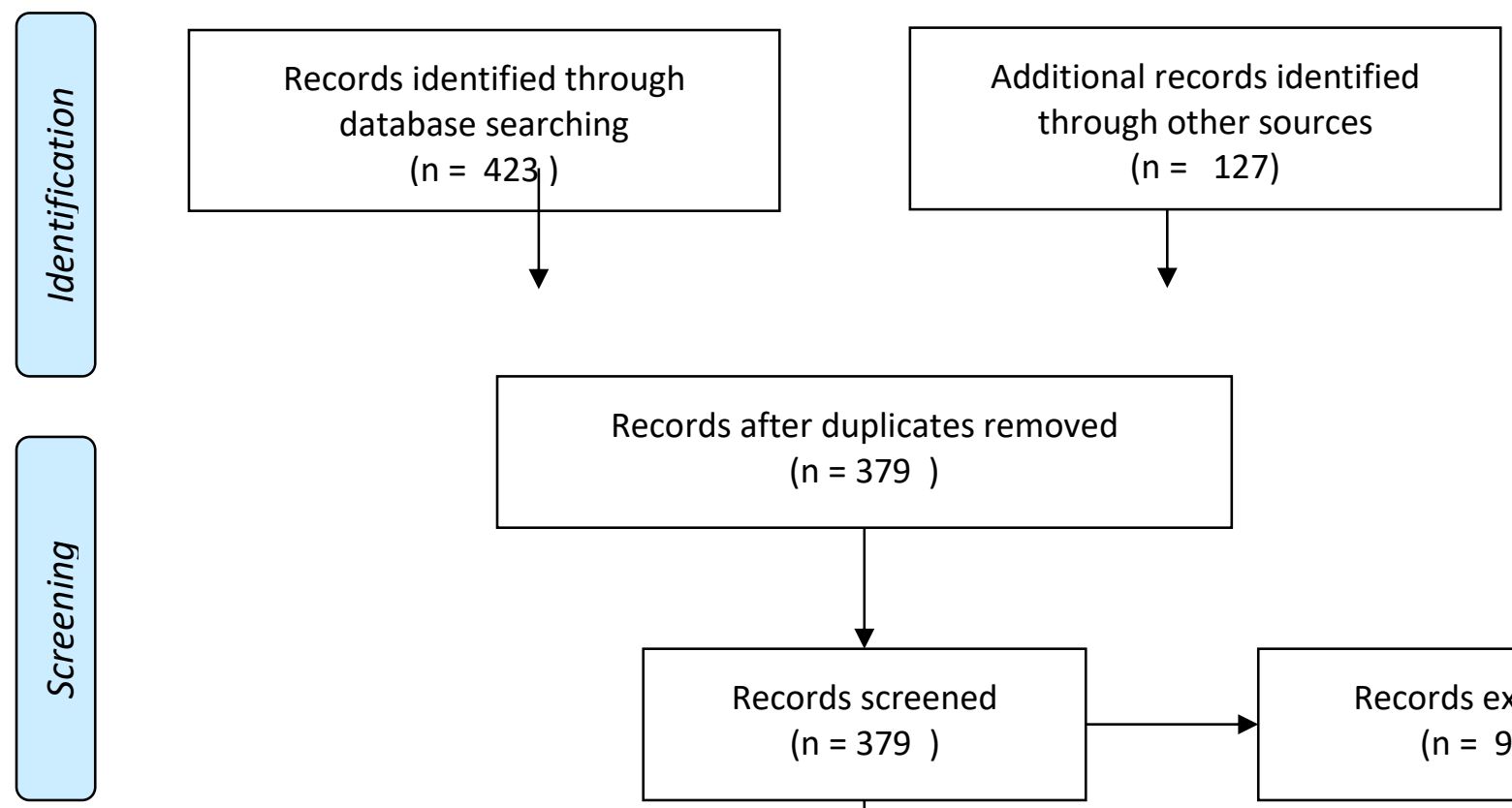

Records after duplicates removed

$$
(n=379 \text { ) }
$$
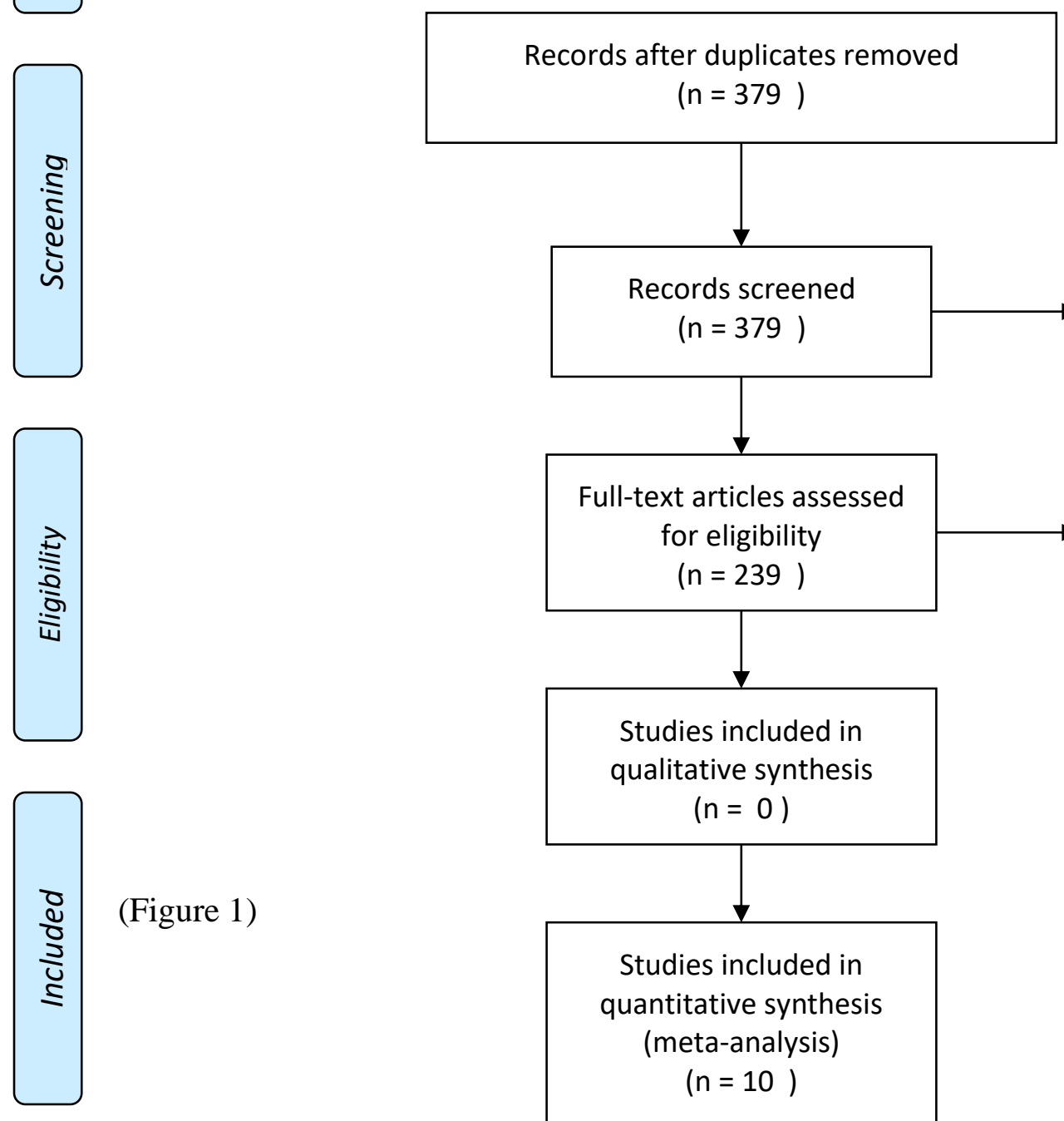
Appendix A

Summary of Primary Research Evidence

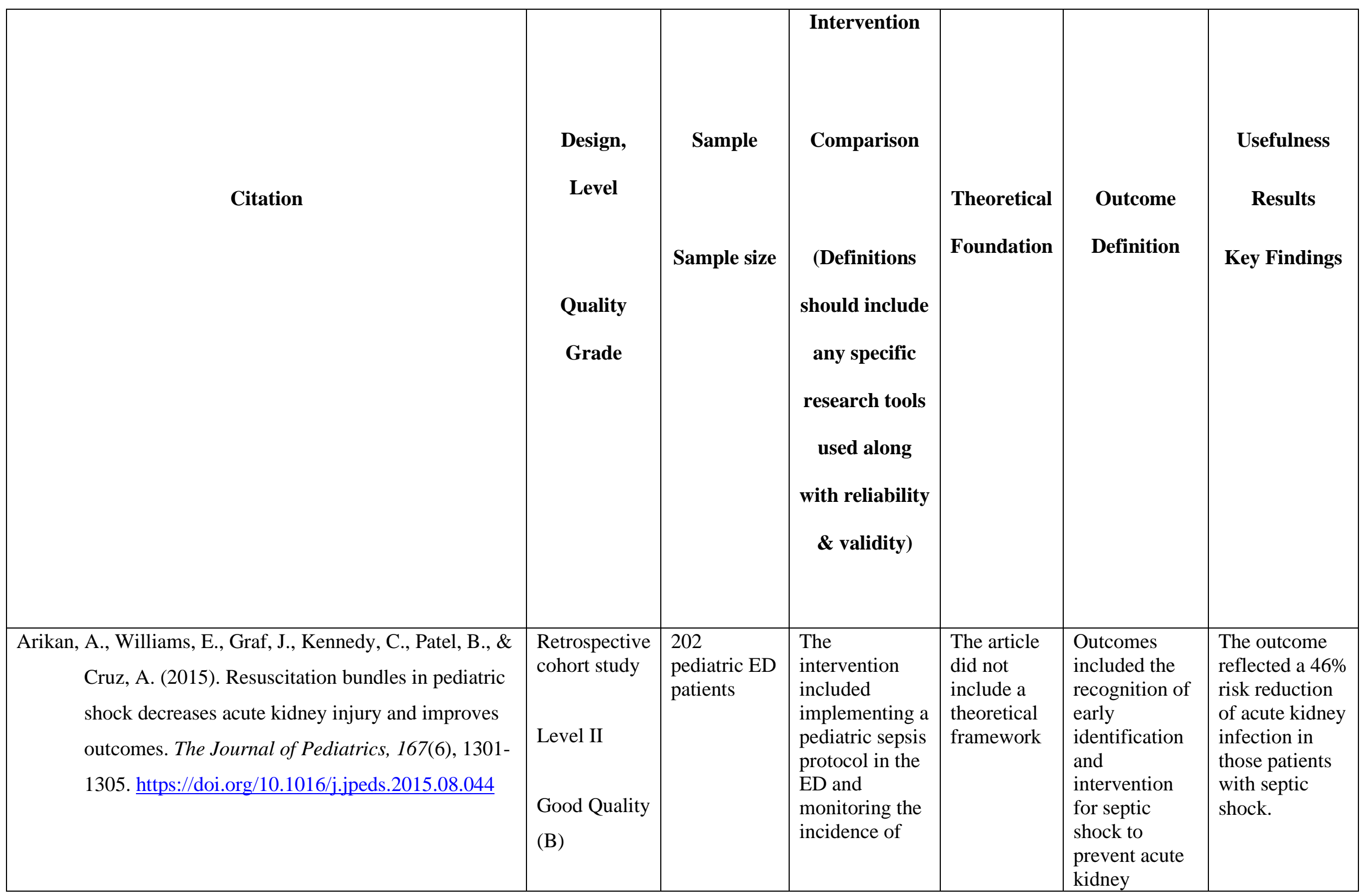




\begin{tabular}{|c|c|c|c|c|c|c|}
\hline & & & $\begin{array}{l}\text { acute kidney } \\
\text { function. } \\
\text { Comparison } \\
\text { included } \\
\text { patients with } \\
\text { septic shock } \\
\text { treated } 12 \\
\text { months before } \\
\text { the protocol } \\
\text { and six months } \\
\text { after the } \\
\text { protocol }\end{array}$ & & $\begin{array}{l}\text { infection in } \\
\text { pediatric } \\
\text { patients. }\end{array}$ & $\begin{array}{l}\text { The reduction } \\
\text { was associated } \\
\text { with decreased } \\
\text { length of stay } \\
\text { and decreased } \\
\text { mortality. }\end{array}$ \\
\hline $\begin{array}{l}\text { Balamuth, F., Alpern, E., Abbadessa, M., Hayes, K., Schast, } \\
\text { A., Lavelle, J., Fitzgerald, J., Weiss, S., \& Zorc, J. } \\
\text { (2017). Improving recognition of pediatric severed } \\
\text { sepsis in the emergency department: Contributions } \\
\text { of a vital sign-based electronic alert and bedside } \\
\text { clinician identification. Annals of Emergency } \\
\text { Medicine, 70(6), 759-768. } \\
\text { https://doi.org/10.1016/j.annemergmed.2017.03.019 }\end{array}$ & $\begin{array}{l}\text { Quality } \\
\text { improvement } \\
\text { cohort study } \\
\text { Level II } \\
\text { Good Quality } \\
\text { (B) }\end{array}$ & $\begin{array}{l}\text { 182,509 ED } \\
\text { visits } \\
(86,037 \\
\text { before sepsis } \\
\text { alert and } \\
96,472 \text { after } \\
\text { sepsis alert } \\
\text { implemented }\end{array}$ & $\begin{array}{l}\text { The } \\
\text { intervention } \\
\text { included } \\
\text { implementation } \\
\text { of a sepsis alert } \\
\text { process in the } \\
\text { ED and } \\
\text { monitoring of } \\
\text { the patients } \\
\text { treated } \\
\text { appropriately } \\
\text { for septic } \\
\text { shock. } \\
\\
\text { Comparison } \\
\text { included } \\
\text { patients treated } \\
\text { for septic shock } \\
\text { twelve months } \\
\text { before } \\
\text { implementation } \\
\text { of the alert } \\
\text { system with }\end{array}$ & $\begin{array}{l}\text { The article } \\
\text { did not } \\
\text { include a } \\
\text { theoretical } \\
\text { framework }\end{array}$ & $\begin{array}{l}\text { The primary } \\
\text { outcome was } \\
\text { appropriate } \\
\text { treatment for } \\
\text { severe sepsis } \\
\text { upon } \\
\text { presentation to } \\
\text { the ED. }\end{array}$ & $\begin{array}{l}\text { Results } \\
\text { included a } \\
\text { mean of } 4 \% \\
\text { missed sepsis } \\
\text { diagnosis } \\
\text { compared to a } \\
\text { mean of } 17 \% \text { a } \\
\text { year prior. } \\
\\
\text { Patients were } \\
\text { more likely to } \\
\text { be correctly } \\
\text { identified and } \\
\text { treated for } \\
\text { sepsis after } \\
\text { implementation } \\
\text { of the sepsis } \\
\text { alert system }\end{array}$ \\
\hline
\end{tabular}




\begin{tabular}{|c|c|c|c|c|c|c|}
\hline & & & $\begin{array}{l}\text { patients after } \\
\text { implementation } \\
\text { of the alert } \\
\text { system. }\end{array}$ & & & \\
\hline $\begin{array}{l}\text { Balamuth, F., Weiss, S., Fitzgerald, J., Hayes, K., } \\
\text { Centkowski, S., Chilutti, M., Grundmeier, R., } \\
\text { Lavelle, J., \& Alpern, E. (2016). Protocolized } \\
\text { treatment is associated with decreased organ } \\
\text { dysfunction in pediatric severe sepsis. Pediatric } \\
\text { Critical Care Medicine, 17(9), 817-822. } \\
\text { https://doi.org/10.1097/PCC.0000000000000858 }\end{array}$ & $\begin{array}{l}\text { Retrospective } \\
\text { cohort study } \\
\text { Level II } \\
\text { High Quality } \\
\text { (A) }\end{array}$ & $\begin{array}{l}189 \\
\text { pediatric } \\
\text { patients in } \\
\text { ED and } \\
\text { PICU }\end{array}$ & $\begin{array}{l}\text { The } \\
\text { intervention } \\
\text { included } \\
\text { comparing data } \\
\text { from the } \\
\text { electronic } \\
\text { health record } \\
\text { (EHR) for } \\
\text { those septic } \\
\text { patients treated } \\
\text { with the } \\
\text { protocol and } \\
\text { those not } \\
\text { treated with the } \\
\text { protocol. } \\
\\
\text { Comparison in } \\
\text { the study } \\
\text { included those } \\
\text { patient treated } \\
\text { with the sepsis } \\
\text { protocol and } \\
\text { those treated } \\
\text { without the } \\
\text { protocol. }\end{array}$ & $\begin{array}{l}\text { The article } \\
\text { did not } \\
\text { include a } \\
\text { theoretical } \\
\text { framework }\end{array}$ & $\begin{array}{l}\text { The primary } \\
\text { outcome } \\
\text { included a } \\
\text { complete } \\
\text { resolution of } \\
\text { any organ } \\
\text { dysfunction by } \\
\text { day } 2\end{array}$ & $\begin{array}{l}\text { Patients treated } \\
\text { with the } \\
\text { protocol had } \\
\text { shorter hospital } \\
\text { stays and } \\
\text { shorter PICU } \\
\text { stays. } \\
\text { Patients treated } \\
\text { with the } \\
\text { protocol were } \\
\text { less likely to be } \\
\text { transferred to a } \\
\text { higher level of } \\
\text { care. } \\
\text { There was no } \\
\text { difference in } \\
\text { hospital } \\
\text { mortality. }\end{array}$ \\
\hline
\end{tabular}




\begin{tabular}{|c|c|c|c|c|c|c|}
\hline $\begin{array}{l}\text { Evans, I., Phillips, G., Alpern, E., Angus, D., Friedrich, M., } \\
\text { \& Kissoon, N. (2018). Association between the } \\
\text { New York sepsis care mandate and in-hospital } \\
\text { mortality for pediatric sepsis. Journal of the } \\
\text { American Medical Association, 320(4), 358-367. } \\
\text { https://doi.org/10.1001/jama.2018.9071 }\end{array}$ & $\begin{array}{l}\text { Cohort study } \\
\text { Level } 1 \\
\text { Good Quality } \\
\text { (B) }\end{array}$ & $\begin{array}{l}1179 \\
\text { pediatric } \\
\text { patients in } \\
\text { ED, ICU, } \\
\text { and inpatient } \\
\text { hospital } \\
\text { units }\end{array}$ & $\begin{array}{l}\text { The } \\
\text { intervention } \\
\text { included } \\
\text { measuring } \\
\text { reported data } \\
\text { from various } \\
\text { hospitals to } \\
\text { determine if the } \\
\text { sepsis protocol } \\
\text { was utilized } \\
\text { within an hour } \\
\text { of arrival to the } \\
\text { ED } \\
\text { Comparison } \\
\text { included those } \\
\text { patients treated } \\
\text { for sepsis } \\
\text { within an hour } \\
\text { of arrival and } \\
\text { those that were } \\
\text { not treated } \\
\text { within an hour } \\
\text { of arrival }\end{array}$ & $\begin{array}{l}\text { The article } \\
\text { did not } \\
\text { include a } \\
\text { theoretical } \\
\text { framework }\end{array}$ & $\begin{array}{l}\text { The primary } \\
\text { outcome } \\
\text { included the } \\
\text { risk-adjusted } \\
\text { in-hospital } \\
\text { mortality rate } \\
\text { for septic } \\
\text { patients }\end{array}$ & $\begin{array}{l}\text { Completion of } \\
\text { the sepsis } \\
\text { bundle within } \\
\text { one hour was } \\
\text { associated with } \\
\text { a lower risk of } \\
\text { in-hospital } \\
\text { mortality. } \\
\text { The entire } \\
\text { sepsis bundle } \\
\text { was completed } \\
\text { in one hour in } \\
24.9 \% \text { of the } \\
\text { patients. }\end{array}$ \\
\hline $\begin{array}{l}\text { Gigli, K., Davis, B., Yabes, J., Chang, C., Angus, D., } \\
\text { Hershey, T., Marin, J., Martsolf, G., \& Kahn, J. } \\
\text { (2020). Pediatric outcomes after regulatory } \\
\text { mandates for sepsis care. Pediatrics, 146(1), } \\
\text { e20193353. https://doi.org/10.1542/peds.2019-3353 }\end{array}$ & $\begin{array}{l}\text { Quasi- } \\
\text { experimental } \\
\text { Level II } \\
\text { Good Quality } \\
\text { (B) }\end{array}$ & $\begin{array}{l}9436 \\
\text { pediatric } \\
\text { patients } \\
\text { from } 237 \\
\text { hospitals }\end{array}$ & $\begin{array}{l}\text { The } \\
\text { intervention } \\
\text { included } \\
\text { measuring } \\
\text { reported data } \\
\text { from various } \\
\text { hospitals to } \\
\text { determine if the } \\
\text { implementation } \\
\text { of mandated } \\
\text { sepsis } \\
\text { regulations } \\
\text { improved }\end{array}$ & $\begin{array}{l}\text { The article } \\
\text { did not } \\
\text { include a } \\
\text { theoretical } \\
\text { framework }\end{array}$ & $\begin{array}{l}\text { The primary } \\
\text { outcome was } \\
\text { in-hospital } \\
\text { mortality in } 30 \\
\text { days after the } \\
\text { date of } \\
\text { admission }\end{array}$ & $\begin{array}{l}\text { Pediatric sepsis } \\
\text { mortality } \\
\text { decreased from } \\
14 \% \text { to } 11.5 \% \text {. }\end{array}$ \\
\hline
\end{tabular}




\begin{tabular}{|c|c|c|c|c|c|c|}
\hline & & & $\begin{array}{l}\text { mortality } \\
\text { trends. } \\
\text { Comparison } \\
\text { included those } \\
\text { patients treated } \\
\text { with the } \\
\text { mandated } \\
\text { regulations in } \\
\text { place and those } \\
\text { not treated with } \\
\text { the mandated } \\
\text { regulations in } \\
\text { place. }\end{array}$ & & & \\
\hline $\begin{array}{l}\text { Lane, R., Funai, T., Reeder, R., \& Larsen, G. (2018). High } \\
\text { reliability pediatric septic shock quality } \\
\text { improvement initiative and decreasing mortality. } \\
\text { Pediatrics, } 138(4), \text { e20154153. } \\
\text { https://doi.org/10.1542/peds.2015-4153 }\end{array}$ & $\begin{array}{l}\text { Quality } \\
\text { improvement } \\
\text { study } \\
\text { Level II } \\
\text { Good Quality } \\
\text { (B) }\end{array}$ & $\begin{array}{l}1380 \\
\text { pediatric } \\
\text { patients }\end{array}$ & $\begin{array}{l}\text { The } \\
\text { intervention } \\
\text { included } \\
\text { implementation } \\
\text { of a sepsis } \\
\text { protocol in the } \\
\text { ED. } \\
\text { Comparison } \\
\text { included those } \\
\text { patients treated } \\
\text { according to } \\
\text { the protocol } \\
\text { and those } \\
\text { patients not } \\
\text { treated } \\
\text { according to } \\
\text { the protocol. }\end{array}$ & $\begin{array}{l}\text { The article } \\
\text { did not } \\
\text { include a } \\
\text { theoretical } \\
\text { framework }\end{array}$ & $\begin{array}{l}\text { The primary } \\
\text { outcome } \\
\text { included an } \\
\text { improved } \\
\text { recognition } \\
\text { and treatment } \\
\text { of septic } \\
\text { shock. }\end{array}$ & $\begin{array}{l}\text { Adherence by } \\
\text { staff to the } \\
\text { protocol } \\
\text { improved from } \\
73 \% \text { to } 84 \% \\
1.2 \% \text { of } \\
\text { patients who } \\
\text { received care } \\
\text { according to } \\
\text { the protocol } \\
\text { died as } \\
\text { compared to } \\
\text { the } 4.2 \% \text { of } \\
\text { patients who } \\
\text { did not receive } \\
\text { care according } \\
\text { to the protocol. }\end{array}$ \\
\hline $\begin{array}{l}\text { Larsen, G., Mecham, N., \& Greenberg, R. (2011). An } \\
\text { emergency department septic shock protocol and } \\
\text { care guideline for children initiated at triage. }\end{array}$ & $\begin{array}{l}\text { Quasi- } \\
\text { experimental } \\
\text { Level II }\end{array}$ & $\begin{array}{l}345 \\
\text { pediatric ED } \\
\text { patients }\end{array}$ & \begin{tabular}{|l|} 
The \\
intervention \\
included \\
measuring \\
reported data
\end{tabular} & $\begin{array}{l}\text { The article } \\
\text { did not } \\
\text { include a } \\
\text { theoretical } \\
\text { framework }\end{array}$ & $\begin{array}{l}\text { The primary } \\
\text { outcomes } \\
\text { included } \\
\text { identifying } \\
\text { patients with }\end{array}$ & $\begin{array}{l}\text { The median } \\
\text { LOS declined } \\
\text { from } 181 \text { hours } \\
\text { to } 140 \text { hours } \\
\text { after }\end{array}$ \\
\hline
\end{tabular}




\begin{tabular}{|c|c|c|c|c|c|c|}
\hline $\begin{array}{l}\text { Pediatrics, } 127(6), \text { e1585. } \\
\text { https://doi.org/10.1542/peds.2010-3513 }\end{array}$ & $\begin{array}{l}\text { Good Quality } \\
\text { (B) }\end{array}$ & & $\begin{array}{l}\text { from various } \\
\text { hospitals to } \\
\text { determine if the } \\
\text { sepsis protocol } \\
\text { was utilized. } \\
\text { Comparison } \\
\text { included those } \\
\text { patients that } \\
\text { were treated } \\
\text { according to } \\
\text { the sepsis } \\
\text { protocol and } \\
\text { those patients } \\
\text { not treated } \\
\text { according to } \\
\text { the protocol. }\end{array}$ & & $\begin{array}{l}\text { early signs and } \\
\text { symptoms of } \\
\text { sepsis, } \\
\text { increasing } \\
\text { compliance } \\
\text { with the sepsis } \\
\text { protocols, and } \\
\text { assess the } \\
\text { impact of the } \\
\text { protocols on } \\
\text { hospital LOS } \\
\text { and mortality }\end{array}$ & $\begin{array}{l}\text { implementation } \\
\text { of the protocol. } \\
\text { The decline in } \\
\text { mortality rate } \\
\text { was from } 7.1 \% \\
\text { to } 6.2 \%\end{array}$ \\
\hline $\begin{array}{l}\text { Lloyd, J., Ahrens, E., Clark, D., Dachenhus, T., \& Nuss, K. } \\
\text { (2018). Automating a manual sepsis screening tool } \\
\text { in a pediatric emergency department. Applied } \\
\text { Clinical Informatics, } 8(4), 803-808 . \\
\text { https://doi.org/10.1055/s-0038-1675211 }\end{array}$ & $\begin{array}{l}\begin{array}{l}\text { Quasi- } \\
\text { experimental }\end{array} \\
\text { Level II } \\
\text { Good Quality } \\
\text { (B) }\end{array}$ & $\begin{array}{l}29 \text { pediatric } \\
\text { patients }\end{array}$ & $\begin{array}{l}\text { The } \\
\text { intervention } \\
\text { included } \\
\text { implementing a } \\
\text { sepsis } \\
\text { screening tool } \\
\text { into the } \\
\text { existing EHR } \\
\text { Comparison } \\
\text { included those } \\
\text { patients treated } \\
\text { with the } \\
\text { manual process } \\
\text { compared to } \\
\text { those treated } \\
\text { with the new } \\
\text { screening tool. }\end{array}$ & $\begin{array}{l}\text { The article } \\
\text { did not } \\
\text { include a } \\
\text { theoretical } \\
\text { framework }\end{array}$ & $\begin{array}{l}\text { The primary } \\
\text { outcome } \\
\text { included an } \\
\text { earlier } \\
\text { intervention of } \\
\text { patients } \\
\text { presenting to } \\
\text { the ED with } \\
\text { sepsis }\end{array}$ & $\begin{array}{l}\text { The screening } \\
\text { tool identified } \\
100 \% \text { of } \\
\text { patients } \\
\text { flagged by the } \\
\text { manual process } \\
68 \text { minutes } \\
\text { earlier }\end{array}$ \\
\hline
\end{tabular}




\begin{tabular}{|c|c|c|c|c|c|c|}
\hline $\begin{array}{l}\text { Long, E., Babl, F., Angley, E., \& Duke, T. (2016). A } \\
\text { prospective quality improvement study in the } \\
\text { emergency department targeting pediatric sepsis. } \\
\text { Archives of Disease in Childhood, 101, 945-950. } \\
\text { https://doi.org/10.1136/archdischild-2015-310234 }\end{array}$ & 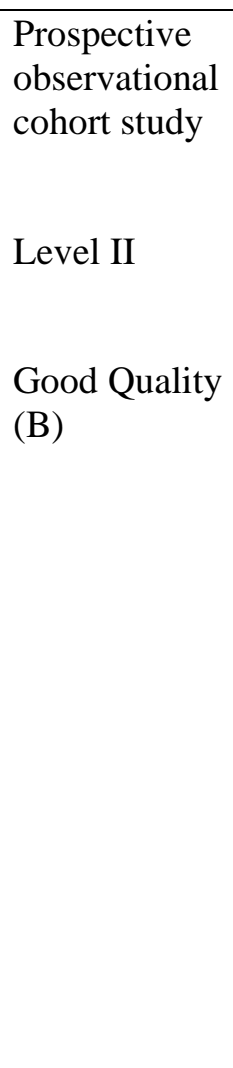 & $\begin{array}{l}102 \\
\text { pediatric } \\
\text { patients }\end{array}$ & $\begin{array}{l}\text { The } \\
\text { intervention } \\
\text { included } \\
\text { assessment of } \\
\text { data collected } \\
\text { before the } \\
\text { protocol was } \\
\text { initiated and } \\
\text { after the } \\
\text { protocol was } \\
\text { initiated. } \\
\text { Comparison } \\
\text { included those } \\
\text { patients that } \\
\text { were treated } \\
\text { according to } \\
\text { the sepsis } \\
\text { protocol and } \\
\text { those patients } \\
\text { not treated } \\
\text { according to } \\
\text { the protocol. }\end{array}$ & $\begin{array}{l}\text { The article } \\
\text { did not } \\
\text { include a } \\
\text { theoretical } \\
\text { framework }\end{array}$ & $\begin{array}{l}\text { The primary } \\
\text { outcome } \\
\text { included early } \\
\text { antibiotic } \\
\text { administration, } \\
\text { timely fluid } \\
\text { resuscitation } \\
\text { therapy, and } \\
\text { venous blood } \\
\text { gas as an } \\
\text { initial } \\
\text { laboratory test. }\end{array}$ & $\begin{array}{l}\text { Hospital LOS } \\
\text { decreased from } \\
96 \text { hours to } 80 \\
\text { hours }\end{array}$ \\
\hline $\begin{array}{l}\text { Mittal, Y., Sankar, J, Dhochak, N., Gupta, S., Lodha, R., \& } \\
\text { Kabra, S. (2019). Decreasing the time to } \\
\text { administration of first dose of antibiotics in children } \\
\text { with severe sepsis. Journal for Healthcare Quality, } \\
\text { 41(1), 32-38. } \\
\text { https://doi.org/10.1097/JHQ.0000000000000141 }\end{array}$ & $\begin{array}{l}\text { Quality } \\
\text { Improvement } \\
\text { Level II } \\
\text { Good Quality } \\
\text { (B) }\end{array}$ & $\begin{array}{l}31 \text { pediatric } \\
\text { patients }\end{array}$ & $\begin{array}{l}\text { Implementation } \\
\text { included } \\
\text { collecting data } \\
\text { from patients } \\
\text { previously } \\
\text { treated in the } \\
\text { ED for sepsis. }\end{array}$ & $\begin{array}{l}\text { The article } \\
\text { did not } \\
\text { include a } \\
\text { theoretical } \\
\text { framework }\end{array}$ & $\begin{array}{l}\text { The primary } \\
\text { outcome was } \\
\text { to reduce the } \\
\text { time of } \\
\text { administration } \\
\text { of the first } \\
\text { does of } \\
\text { antibiotic for } \\
\text { pediatric } \\
\text { septic patients }\end{array}$ & $\begin{array}{l}\text { The median } \\
\text { time for } \\
\text { administration } \\
\text { of antibiotics } \\
\text { decreased from } \\
50 \text { minutes to } \\
20 \text { minutes } \\
\text { The median } \\
\text { time for } \\
\text { recognition of } \\
\text { sepsis } \\
\text { decreased from }\end{array}$ \\
\hline
\end{tabular}




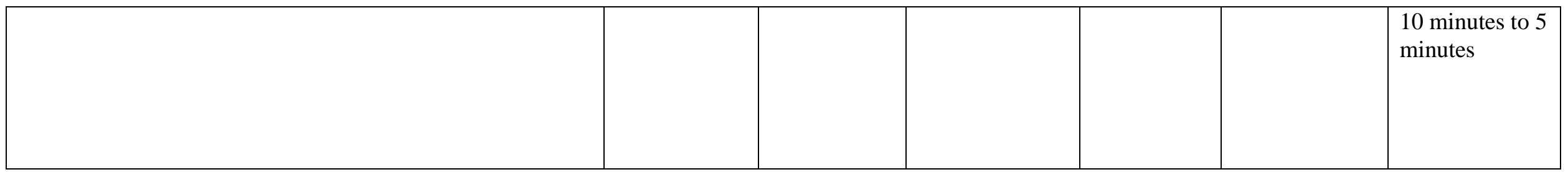


Appendix B

Summary of Systematic Reviews (SR)

\begin{tabular}{|c|c|c|c|c|c|c|c|}
\hline Citation & $\begin{array}{l}\text { Quality } \\
\text { Grade }\end{array}$ & Question & Search Strategy & $\begin{array}{l}\text { Inclusion/ } \\
\text { Exclusion Criteria }\end{array}$ & $\begin{array}{l}\text { Data Extraction and } \\
\text { Analysis }\end{array}$ & Key Findings & $\begin{array}{l}\text { Usefulness/Recom } \\
\text { mendation/ } \\
\text { Implications }\end{array}$ \\
\hline $\begin{array}{l}\text { Akech, S., } \\
\text { Ledermann, H., \& } \\
\text { Maitland, K. (2010). } \\
\text { Choice of fluids for } \\
\text { resuscitation in } \\
\text { children with severe } \\
\text { infection and shock: } \\
\text { Systematic review. } \\
\text { British Medical } \\
\text { Journal, } 341, \text { c4416. } \\
\text { https://doi.org/10.113 } \\
\text { 6/bmj.c4416 } \\
\end{array}$ & $\begin{array}{l}\text { B } \\
\text { (Good } \\
\text { Quality) } \\
\\
\\
\\
\end{array}$ & $\begin{array}{l}\text { Whether the use } \\
\text { of crystalloids } \\
\text { or colloids is } \\
\text { more effective } \\
\text { in the treatment } \\
\text { of pediatric } \\
\text { sepsis }\end{array}$ & $\begin{array}{l}\text { Searches used } \\
\text { included Medline, } \\
\text { PubMed, the } \\
\text { Cochrane Library, } \\
\text { and EMBASE }\end{array}$ & $\begin{array}{l}\text { Inclusion criteria: studies } \\
\text { that included patients with } \\
\text { sepsis-like conditions } \\
\text { Exclusion criteria: studies } \\
\text { that included patients with } \\
\text { burns, trauma, surgical } \\
\text { conditions, and } \\
\text { gastroenteritis }\end{array}$ & $\begin{array}{l}\text { Six trials were } \\
\text { selected that included } \\
811 \text { participants, } 523 \\
\text { used colloids and } 288 \\
\text { crystalloids with } 48 \\
\text { reported deaths. }\end{array}$ & $\begin{array}{l}\text { There is an improved } \\
\text { outcome for children } \\
\text { receiving colloids for } \\
\text { fluid resuscitation in } \\
\text { shock }\end{array}$ & \begin{tabular}{|l|} 
Broad based trials \\
are needed to \\
compare the \\
efficacy of colloids \\
and crystalloids
\end{tabular} \\
\hline $\begin{array}{l}\text { Ford, N., Hargreaves, } \\
\text { S., \& Shanks, L. } \\
\text { (2012). Mortality } \\
\text { after fluid bolus in } \\
\text { children with shock } \\
\text { due to sepsis or } \\
\text { severe infection: A } \\
\text { systematic review } \\
\text { and meta-analysis. } \\
\text { PLOS One, } 7(8), \\
\text { e43953. } \\
\text { https://doi.org/10.137 } \\
1 \text { journal.pone.00439 } \\
53\end{array}$ & \begin{tabular}{|l|} 
A (High \\
Quality) \\
\end{tabular} & $\begin{array}{l}\text { Whether or not } \\
\text { fluid boluses in } \\
\text { children with } \\
\text { septic shock } \\
\text { improve } \\
\text { outcomes }\end{array}$ & $\begin{array}{l}\text { Searches used } \\
\text { included MEDLINE, } \\
\text { EMBASE, and } \\
\text { Cochrane Central }\end{array}$ & $\begin{array}{l}\text { Inclusion criteria: children } \\
\text { treated with a fluid bolus } \\
\text { during septic shock } \\
\text { Exclusion criteria: children } \\
\text { not in septic shock, children } \\
\text { with malnutrition, and child } \\
\text { in fluid refractory shock }\end{array}$ & $\begin{array}{l}\text { Studies used included } \\
\text { populations with } \\
\text { malaria, dengue } \\
\text { fever, and septic } \\
\text { shock }\end{array}$ & $\begin{array}{l}\text { Fluid boluses are } \\
\text { harmful to children in } \\
\text { shock as compared to no } \\
\text { fluid bolus. }\end{array}$ & \begin{tabular}{|l|} 
Algorithms and \\
guidelines are \\
needed to determine \\
which children will \\
benefit from fluid \\
boluses and which \\
children will be \\
harmed.
\end{tabular} \\
\hline $\begin{array}{l}\text { Tan, B., Wong, J., } \\
\text { Sultana, R., Koh, J., } \\
\text { Jit, M., Mok, Y., \& } \\
\text { Lee, J. (2019). Global } \\
\text { case-fatality rates in }\end{array}$ & A (High & $\begin{array}{l}\text { What are the } \\
\text { global trends of } \\
\text { case-fatality } \\
\text { risk in pediatric } \\
\text { sepsis? }\end{array}$ & $\begin{array}{l}\text { Searches used } \\
\text { included PubMed, } \\
\text { Web of Science, } \\
\text { Excerpta Medica }\end{array}$ & $\begin{array}{l}\text { Inclusion criteria: children } \\
\text { with sepsis that reported } \\
\text { case-fatality rates were used } \\
\text { Exclusion criteria: neonates }\end{array}$ & $\begin{array}{l}94 \text { studies that } \\
\text { included } 7651 \\
\text { children with } \\
\text { reported sepsis }\end{array}$ & $\begin{array}{l}\text { There was a declining } \\
\text { trend of case-fatality risk } \\
\text { in pediatric sepsis with } \\
\text { significant disparities }\end{array}$ & $\begin{array}{l}\text { Characterizations of } \\
\text { vulnerable } \\
\text { populations and } \\
\text { collaborations } \\
\text { between developing }\end{array}$ \\
\hline
\end{tabular}




\begin{tabular}{|c|c|c|c|c|c|c|c|}
\hline Citation & $\begin{array}{l}\text { Quality } \\
\text { Grade }\end{array}$ & Question & Search Strategy & $\begin{array}{l}\text { Inclusion/ } \\
\text { Exclusion Criteria }\end{array}$ & $\begin{array}{l}\text { Data Extraction and } \\
\text { Analysis }\end{array}$ & Key Findings & $\begin{array}{l}\text { Usefulness/Recom } \\
\text { mendation/ } \\
\text { Implications }\end{array}$ \\
\hline $\begin{array}{l}\text { pediatric severe } \\
\text { sepsis and septic } \\
\text { shock. A systematic } \\
\text { review and meta- } \\
\text { analysis. JAMA } \\
\text { Pediatrics, } 173(4), \\
\text { 352-361. } \\
\text { https://doi.org/10.100 } \\
1 / \text { jamapediatrics.201 } \\
8.4839 \\
\end{array}$ & & & $\begin{array}{l}\text { database, CINAHL, } \\
\text { and Cochrane Central }\end{array}$ & & & $\begin{array}{l}\text { between developing } \\
\text { countries }\end{array}$ & $\begin{array}{l}\text { countries are } \\
\text { needed to reduce } \\
\text { the burden of } \\
\text { pediatric sepsis on a } \\
\text { global level }\end{array}$ \\
\hline $\begin{array}{l}\text { Yoon, S., Kim, H., \& } \\
\text { Ahn, J. (2019). } \\
\text { Presepsin as a } \\
\text { diagnostic marker of } \\
\text { sepsis in children and } \\
\text { adolescents: A } \\
\text { systematic review } \\
\text { and meta-analysis. } \\
\text { BMC Infectious } \\
\text { Diseases, } 19,760 . \\
\text { https://doi.org/10.118 } \\
6 / \text { s12879-019-4397-1 } \\
\end{array}$ & $\begin{array}{l}\text { A (High } \\
\text { Quality) }\end{array}$ & $\begin{array}{l}\text { What is the } \\
\text { diagnostic value } \\
\text { of presepsin in } \\
\text { pediatric sepsis }\end{array}$ & $\begin{array}{l}\text { Searches used } \\
\text { included Medline, } \\
\text { PubMed, EMBASE, } \\
\text { the Cochrane Library, } \\
\text { and ISI Web of } \\
\text { Science }\end{array}$ & $\begin{array}{l}\text { Inclusion criteria: studies } \\
\text { providing the accuracy of } \\
\text { presepsin in the diagnosis of } \\
\text { pediatric sepsis } \\
\text { Exclusion criteria: studies } \\
\text { not separately considering } \\
\text { pediatric patients and } \\
\text { studies not addressing sepsis } \\
\text { or presepsin }\end{array}$ & \begin{tabular}{|l|} 
Three studies that \\
included three \\
hundred eight \\
patients-207 patients \\
in the control group \\
and were not septic \\
and 101 patients with \\
sepsis
\end{tabular} & $\begin{array}{l}\text { Presepsin showed a } \\
\text { higher sensitivity and } \\
\text { accuracy but a lower } \\
\text { specificity for the } \\
\text { diagnosis of sepsis than } \\
\text { C-reactive protein and } \\
\text { procalcitonin }\end{array}$ & $\begin{array}{l}\text { Future clinical trials } \\
\text { are needed to } \\
\text { determine the } \\
\text { optimal presepsin } \\
\text { cutoff for the } \\
\text { diagnosis of sepsis } \\
\text { in children }\end{array}$ \\
\hline
\end{tabular}


Appendix C

\section{SWOT Analysis}

\section{Strengths}

Stakeholder support for the project-stakeholder interest and input in project

Monetary support-organization willing to provide the money to fund the project

\section{Weaknesses}

Resistance by staff to utilize protocol

No active protocol in place

\section{Opportunities}

Implementation of the project in other pediatric EDs in the organization

\section{Threats}

Poor health and treatment outcomes for pediatric septic patients

Staff quitting if forced to use the protocol 
Appendix D

\section{Project Schedule}

\begin{tabular}{|c|c|c|c|c|c|c|c|c|c|c|c|c|c|c|c|c|c|c|c|c|c|c|c|c|}
\hline & \multicolumn{8}{|c|}{ NUR7801 } & \multicolumn{8}{|c|}{ NUR7802 } & \multicolumn{8}{|c|}{ NUR7803 } \\
\hline 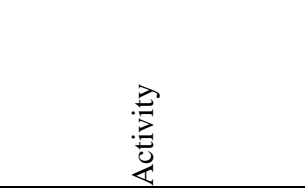 & $\begin{array}{l}\stackrel{1}{1} \\
\frac{\pi}{D} \\
\frac{D}{3}\end{array}$ & 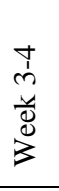 & 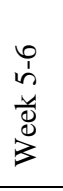 & 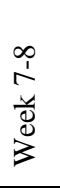 & $\begin{array}{l}\text { 임 } \\
\text { à } \\
\frac{y}{8} \\
\frac{d}{3}\end{array}$ & $\begin{array}{l}\text { I } \\
\Xi \\
\frac{1}{ \pm} \\
3\end{array}$ & 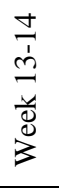 & $\begin{array}{l}\frac{n}{4} \\
\frac{\pi}{d} \\
3\end{array}$ & $\begin{array}{l}\frac{N}{\Delta} \\
\frac{\pi}{3}\end{array}$ & $\begin{array}{l}+ \\
\dot{1} \\
m \\
\frac{1}{d} \\
3\end{array}$ & 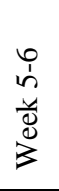 & 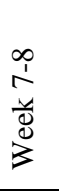 & $\begin{array}{l}0 \\
a \\
a \\
\frac{y}{2} \\
3\end{array}$ & $\begin{array}{l}\stackrel{I}{I} \\
= \\
\frac{4}{0} \\
3\end{array}$ & 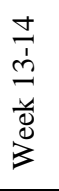 & $\begin{array}{l}\frac{n}{3} \\
\frac{y}{d} \\
\frac{d}{3}\end{array}$ & $\begin{array}{l}\frac{\bar{y}}{2} \\
\frac{0}{3}\end{array}$ & $\frac{m}{\frac{n}{0}}$ & $\begin{array}{l}n \\
\frac{n}{0} \\
3 \\
3\end{array}$ & $\frac{\bar{y}}{\frac{y}{0}}$ & $\begin{array}{l}a \\
\frac{y}{0} \\
3\end{array}$ & $\begin{array}{l}= \\
\frac{y}{D} \\
z\end{array}$ & $\begin{array}{l}\frac{m}{2} \\
\frac{y}{D} \\
\frac{D}{3}\end{array}$ & $\begin{array}{l}n \\
\frac{n}{d} \\
\frac{d}{3}\end{array}$ \\
\hline Meet with preceptor & & $\mathrm{X}$ & & $\mathrm{X}$ & & $\mathrm{X}$ & & $\mathrm{X}$ & & & & & & & & & & & & & & & & \\
\hline $\begin{array}{l}\text { Determine the need for } \\
\text { the project }\end{array}$ & $\mathrm{X}$ & & & & & & & & & & & & & & & & & & & & & & & \\
\hline Identify stakeholders & & $\mathrm{X}$ & & & & & & & & & & & & & & & & & & & & & & \\
\hline $\begin{array}{l}\text { Attend webinars on } \\
\text { leadership and project } \\
\text { planning }\end{array}$ & $\mathrm{X}$ & & $\mathrm{X}$ & & $\mathrm{X}$ & & $\mathrm{X}$ & & & & & & & & & & & & & & & & & \\
\hline $\begin{array}{l}\text { Meeting with } \\
\text { stakeholders to discuss } \\
\text { project proposal }\end{array}$ & & $\mathrm{X}$ & & & & $\mathrm{X}$ & & & & & & & & & & & & & & & & & & \\
\hline $\begin{array}{l}\text { Work on project } \\
\text { proposal }\end{array}$ & $\mathrm{X}$ & $\mathrm{X}$ & $\mathrm{X}$ & $\mathrm{X}$ & $\mathrm{X}$ & $\mathrm{X}$ & $\mathrm{X}$ & $\mathrm{X}$ & & & & & & & & & & & & & & & & \\
\hline $\begin{array}{l}\text { Meet/collaborate with } \\
\text { preceptor }\end{array}$ & & & & & & & & & $\mathrm{X}$ & $\mathrm{X}$ & $\mathrm{X}$ & $\mathrm{X}$ & $X$ & $\mathrm{X}$ & $\mathrm{X}$ & & & & & & & & & \\
\hline $\begin{array}{l}\text { Complete proposal for } \\
\text { IRB review }\end{array}$ & & & & & & & & & $\mathrm{X}$ & & & & & & & & & & & & & & & \\
\hline $\begin{array}{l}\text { Submit proposal to } \\
\text { IRB for review }\end{array}$ & & & & & & & & & & $\mathrm{X}$ & & & & & & & & & & & & & & \\
\hline $\begin{array}{l}\text { Protocol placed into } \\
\text { EPIC }\end{array}$ & & & & & & & & & & $\mathrm{X}$ & & & & & & & & & & & & & & \\
\hline $\begin{array}{l}\text { Staff training on use of } \\
\text { protocol }\end{array}$ & & & & & & & & & & $\mathrm{X}$ & $\mathrm{X}$ & $\mathrm{X}$ & X & & & & & & & & & & & \\
\hline $\begin{array}{l}\text { Meeting with sepsis } \\
\text { QI team }\end{array}$ & & & & & & & & & & $\mathrm{X}$ & & $\mathrm{X}$ & & $\mathrm{X}$ & & $\mathrm{X}$ & & & & & & & & \\
\hline & & & & & & & & & & & & & & & & & & & & & & & & \\
\hline
\end{tabular}




\begin{tabular}{|c|c|c|c|c|c|c|c|c|c|c|c|c|c|c|c|c|c|c|c|c|c|c|c|c|}
\hline & \multicolumn{8}{|c|}{ NUR7801 } & \multicolumn{8}{|c|}{ NUR7802 } & \multicolumn{8}{|c|}{ NUR7803 } \\
\hline 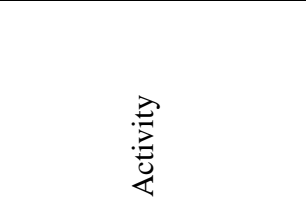 & $\begin{array}{l}\frac{N}{I} \\
\frac{\pi}{d} \\
\stackrel{D}{3}\end{array}$ & 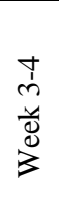 & 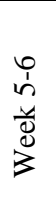 & 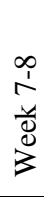 & 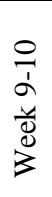 & $\begin{array}{l}\text { I } \\
\stackrel{J}{J} \\
\frac{4}{8} \\
3\end{array}$ & $\begin{array}{l}\frac{\Delta}{d} \\
\frac{\Delta}{\Delta} \\
\frac{u}{3}\end{array}$ & $\begin{array}{l}\frac{n}{\pi} \\
\frac{\pi}{3} \\
3\end{array}$ & $\frac{i}{\frac{1}{d}}$ & 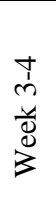 & $\begin{array}{l}0 \\
\stackrel{1}{n} \\
\ddot{d} \\
\stackrel{d}{3}\end{array}$ & 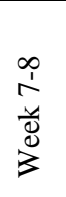 & $\begin{array}{l}0 \\
\vdots \\
a \\
\frac{v}{d} \\
\frac{d}{3}\end{array}$ & $\begin{array}{l}\stackrel{I}{I} \\
= \\
\frac{u}{J} \\
3\end{array}$ & $\begin{array}{l}\frac{\Delta}{\dot{m}} \\
\frac{u}{d} \\
\frac{d}{3}\end{array}$ & $\begin{array}{l}\frac{n}{\pi} \\
\frac{\pi}{0} \\
3\end{array}$ & $\begin{array}{l}\bar{\pi} \\
\frac{\pi}{3} \\
3\end{array}$ & $\begin{array}{l}\frac{m}{\ddot{\nu}} \\
\frac{\pi}{3}\end{array}$ & $\begin{array}{l}n \\
\frac{n}{0} \\
3\end{array}$ & $\frac{\bar{y}}{\overline{0}}$ & $\begin{array}{l}a \\
\frac{\vec{u}}{3} \\
3\end{array}$ & $\begin{array}{l}= \\
\frac{\pi}{0} \\
3\end{array}$ & $\begin{array}{l}\frac{3}{1} \\
\frac{4}{0} \\
3\end{array}$ & $\begin{array}{l}\frac{n}{4} \\
\frac{4}{0} \\
3\end{array}$ \\
\hline $\begin{array}{l}\text { Implementation of } \\
\text { protocol in Peds ED }\end{array}$ & & & & & & & & & & & $\mathrm{X}$ & & & & & & & & & & & & & \\
\hline Data Collection & & & & & & & & & & & $\mathrm{X}$ & $\mathrm{X}$ & $X$ & $\mathrm{X}$ & $\mathrm{X}$ & & & & & & & & & \\
\hline Analysis of Data & & & & & & & & & & & & & & & $\mathrm{X}$ & & & & & & & & & \\
\hline Completion of project & & & & & & & & & & & & & & & & $\mathrm{X}$ & & & & & & & & \\
\hline & & & & & & & & & & & & & & & & & & & & & & & & \\
\hline & & & & & & & & & & & & & & & & & & & & & & & & \\
\hline & & & & & & & & & & & & & & & & & & & & & & & & \\
\hline & & & & & & & & & & & & & & & & & & & & & & & & \\
\hline & & & & & & & & & & & & & & & & & & & & & & & & \\
\hline
\end{tabular}


Appendix E

\section{Pathway \\ QYes
No}

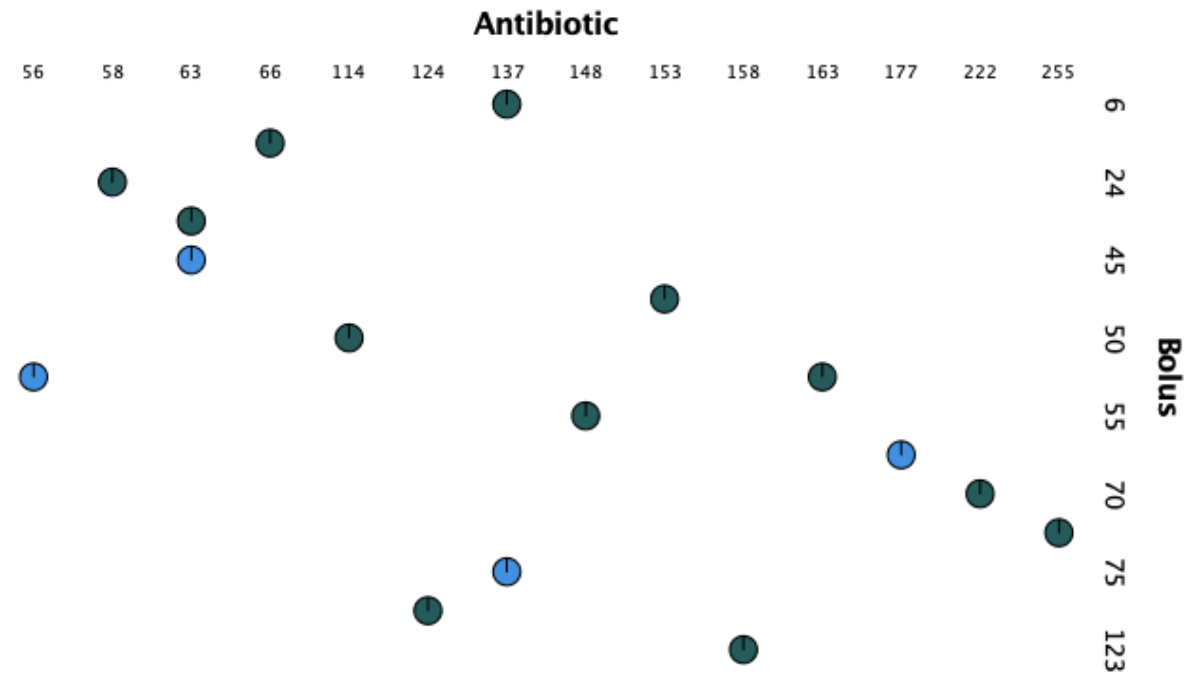




\section{Appendix F}

\section{Relationship Map}

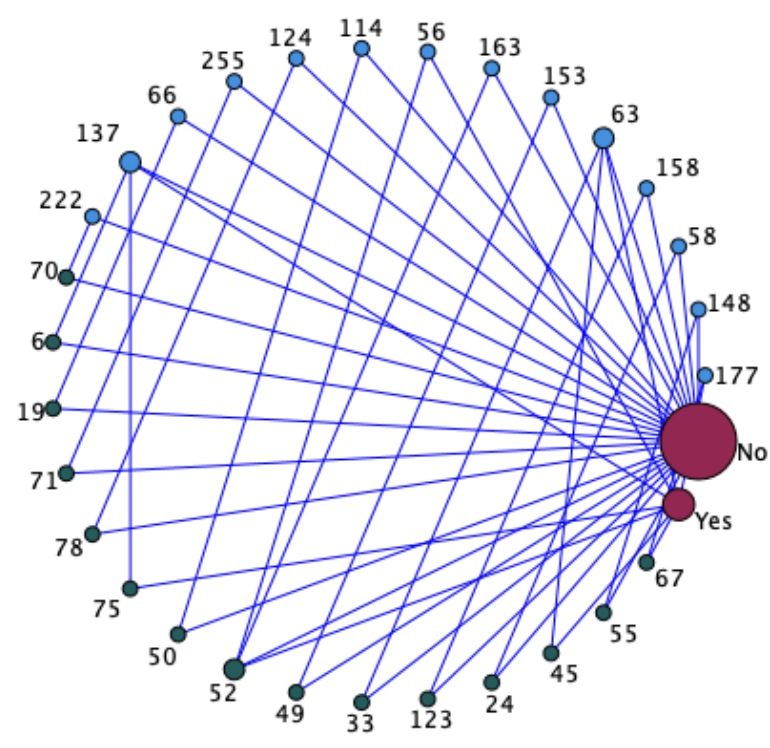

\section{Variable}

O Antibiotic O Pathway

Bolus

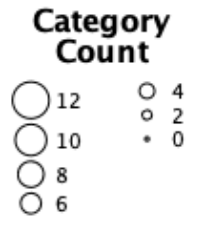

\section{Relationship} Count 


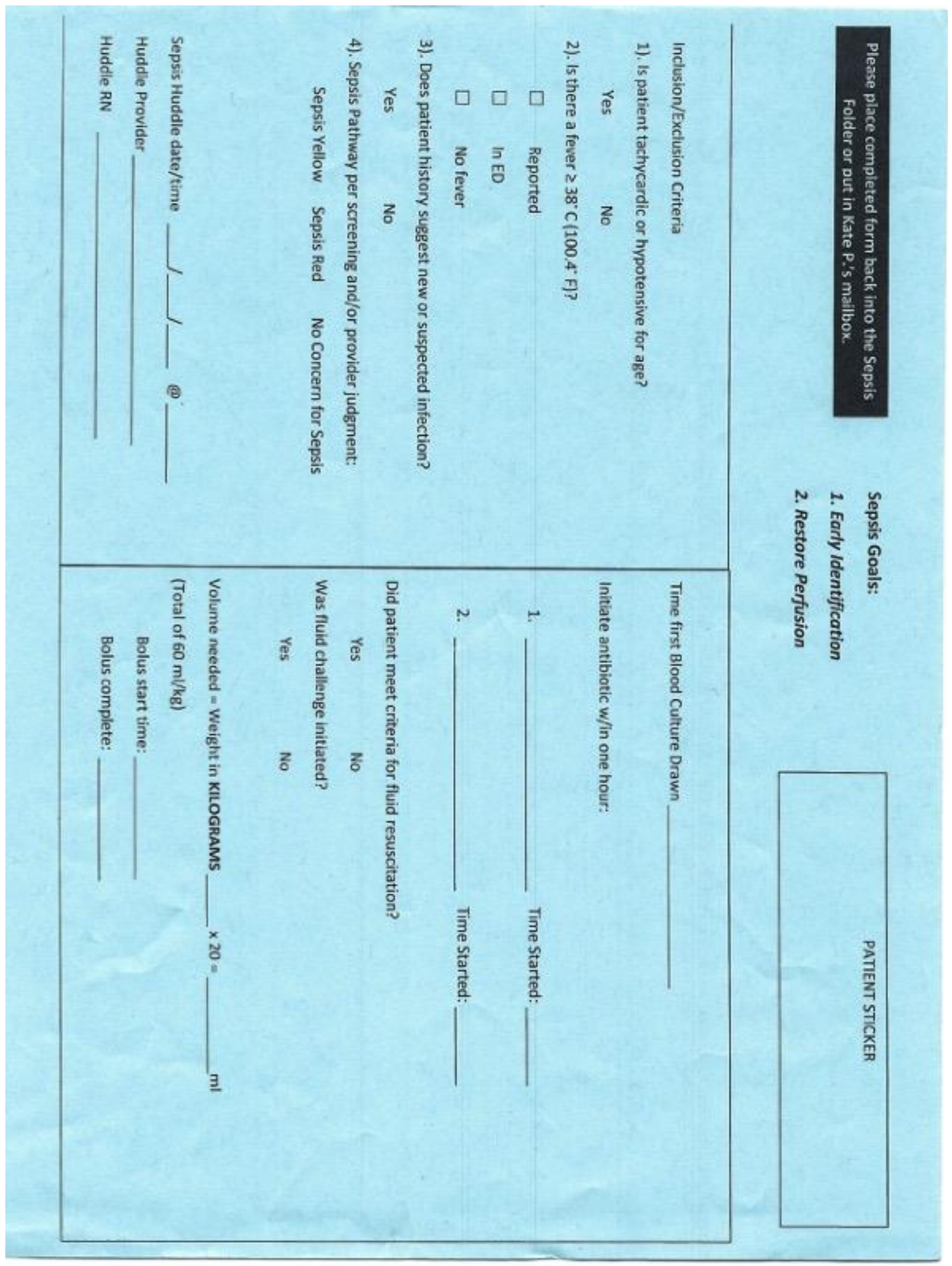


Appendix $\mathrm{H}$

Pre-Intervention Data

\begin{tabular}{|l|c|c|c|c|c|c|c|c|c|c}
\hline MRN & DOS & Triage & $\begin{array}{c}\text { IV Bolus } \\
\text { ordered }\end{array}$ & $\begin{array}{c}\text { Min to } \\
\text { bolus } \\
\text { order }\end{array}$ & $\begin{array}{c}\text { Time } \\
\text { bolus } \\
\text { given }\end{array}$ & $\begin{array}{c}\text { Min } \\
\text { to } \\
\text { bolus } \\
\text { given }\end{array}$ & $\begin{array}{c}\text { Time } \\
\text { antibiotic } \\
\text { ordered }\end{array}$ & $\begin{array}{c}\text { Min to } \\
\text { antibiotic } \\
\text { order }\end{array}$ & $\begin{array}{c}\text { Time } \\
\text { antibioti } \\
\text { c given }\end{array}$ & $\begin{array}{c}\text { Min to } \\
\text { antibiot }\end{array}$ \\
\hline 1004642 & $8 / 19 / 20$ & 1834 & 1900 & 26 & 1924 & 50 & 2003 & 89 & 2028 & 114 \\
\hline 012925122 & $2 / 5 / 20$ & 1409 & 1420 & 11 & 1519 & 70 & 1420 & 11 & 1751 & 222 \\
\hline 012895210 & $2 / 6 / 20$ & 1329 & 1335 & 6 & 1545 & 136 & 1335 & 6 & 1546 & 137 \\
\hline 05221391 & $3 / 15 / 20$ & 1752 & 1752 & 0 & 1910 & 78 & 1943 & 111 & 1956 & 124 \\
\hline 01019325 & $6 / 22 / 20$ & 1718 & 1912 & 114 & 1921 & 123 & 1943 & 145 & 1956 & 158 \\
\hline 0973997 & $1 / 7 / 20$ & 1132 & 1202 & 30 & 1224 & 52 & 1311 & 99 & 1416 & 163 \\
\hline 05647806 & $4 / 1 / 20$ & 1833 & 1927 & 54 & 1927 & 49 & 2121 & 168 & 2105 & 152 \\
\hline 01136543 & $7 / 14 / 20$ & 1907 & 1927 & 20 & 1931 & 24 & 1933 & 26 & 2005 & 58 \\
\hline 10641144 & $7 / 17 / 20$ & 2125 & 2129 & 4 & 2220 & 55 & 2258 & 93 & 2353 & 148 \\
\hline 102438005 & $8 / 15 / 20$ & 2012 & 2015 & 3 & 2045 & 33 & 2018 & 6 & 2115 & 63 \\
\hline To918829 & $11 / 5 / 20$ & 1159 & 1236 & 37 & 1310 & 71 & 1541 & 222 & 1614 & 255 \\
\hline Minutes & & & & $\mathbf{3 2 4}$ & & $\mathbf{7 6 0}$ & & $\mathbf{1 0 0 5}$ & & $\mathbf{1 6 6 0}$ \\
\hline Iean Avg & & & & & & & & & & $\mathbf{8 3 . 8}$ \\
\hline
\end{tabular}


Appendix I

Post-Intervention Data

\begin{tabular}{|c|c|c|c|c|c|c|c|c|c|c|c|}
\hline MRN & DOS & $\begin{array}{c}\text { Triage } \\
\text { Time }\end{array}$ & $\begin{array}{c}\text { IV } \\
\text { Bolus } \\
\text { ordered }\end{array}$ & $\begin{array}{c}\text { Min to } \\
\text { bolus } \\
\text { order }\end{array}$ & $\begin{array}{l}\text { Time } \\
\text { bolus } \\
\text { given }\end{array}$ & $\begin{array}{c}\text { Minutes } \\
\text { to bolus } \\
\text { given }\end{array}$ & $\begin{array}{c}\text { Time } \\
\text { antibiotic } \\
\text { ordered }\end{array}$ & $\begin{array}{c}\text { Min to } \\
\text { antibiotic } \\
\text { order }\end{array}$ & $\begin{array}{c}\text { Time } \\
\text { antibiotic } \\
\text { given }\end{array}$ & $\begin{array}{c}\text { Minutes } \\
\text { to } \\
\text { antibiotic }\end{array}$ & $\begin{array}{c}\text { Huddle } \\
\text { done }\end{array}$ \\
\hline 1011511289 & $5 / 21 / 21$ & 1712 & 1712 & 0 & 1800 & 52 & 1712 & 0 & 1804 & 56 & Yes \\
\hline 005493320 & $6 / 14 / 21$ & 1128 & 1201 & 33 & 1235 & 67 & 1337 & 129 & 1425 & 177 & Yes \\
\hline 1014080794 & $6 / 9 / 21$ & 1638 & 1649 & 11 & 1723 & 45 & 1650 & 12 & 1741 & 63 & Yes \\
\hline 001716811 & $6 / 12 / 21$ & 1416 & 1516 & 60 & 1531 & 75 & 1618 & 122 & 1633 & 137 & Yes \\
\hline Total Minutes & & & & 104 & & 239 & & 263 & & 433 & \\
\hline Mean Avg & & & & 26 & & 59.8 & & 65.8 & & 108.3 & \\
\hline
\end{tabular}




\section{Appendix $\mathbf{J}$}

February 28, 2021

Dr. Douglas Turner PhD, DNP, RN, CNE, NE-BC, NEA-BC

University of St. Augustine

1 University Boulevard

St. Augustine, Florida 32086

Dear Dr. Turner,

I am writing this letter to confirm that University of St. Augustine DNP student Roslyn Smiley-Lampkin has been approved through our organization to conduct her Evidence-Based Practice Project entitled Pediatric Sepsis:

Development of a Clinical Pathway for the Pediatric Emergency Department.

We are excited to be working with Roslyn on this important topic and her work will help us to reach our goal of identifying septic children early and intervene aggressively to improve outcomes. The preparatory work has been in progress for several months and the project is ready for implementation.

Please feel free to contact me with any questions that may arise.

Sincerely,

Janis Quinn DNP, APRN, CPNP-AC

Pediatric Nurse Practitioner

Pediatric Emergency Department

She/Her/Hers

Ann \& Robert H. Lurie Children's Hospital of Chicago at Central DuPage Hospital

Mobile phone: 331-229-6060

jquinn@luriechildrens.org

Janis.Quinn@nm.org

Sender's Name

Title 